\title{
Biochar affects the structure rather than the total biomass of microbial communities in temperate soils
}

\author{
Elena Anders ${ }^{1,2}$, Andrea Watzinger ${ }^{1 *}$, Franziska Rempt ${ }^{1,3}$, Barbara Kitzler ${ }^{4}$, Bernhard Wimmer ${ }^{1}$, Franz Zehetner ${ }^{2}$, Karl \\ Stahr ${ }^{3}$, Sophie Zechmeister-Boltenstern ${ }^{2}$ and Gerhard Soja ${ }^{1}$ \\ ${ }^{1}$ Environmental Resources and Technologies, Health and Environment Department, AIT Austrian Institute of Technology GmbH, \\ Konrad-Lorenz-Strasse 24, 3430 Tulln, Austria \\ ${ }^{2}$ Institute of Soil Research, Department of Forestry and Soil Sciences, University of Natural Resources and Life Sciences, \\ Peter-Jordan-Strasse 82, 1190 Vienna, Austria \\ ${ }^{3}$ Institute of Soil Science and Land Evaluation, University Hohenheim, Emil-Wolff-Strasse 27, 70599 Stuttgart, Germany \\ ${ }^{4}$ Institute of Soil Biology, Federal Research and Training Centre for Forests, Natural Hazards and Landscape, 1131 Vienna, \\ Austria \\ e-mail: andrea.watzinger@ait.ac.at
}

\begin{abstract}
Biochar application is a promising strategy for sequestering carbon in agricultural soils and for improving degraded soils. Nonetheless, contradictory and unsettled issues remain. This study investigates whether biochar influences the soil microbial biomass and community structure using phospholipid fatty acid (PLFA) analysis. We monitored the effects of four different types of biochar on the soil microbial communities in three temperate soils of Austria over several months. A greenhouse experiment and two field experiments were conducted. The biochar application did not significantly increase or decrease the microbial biomass. Only the addition of vineyard pruning biochar pyrolysed at $400^{\circ} \mathrm{C}$ caused microbial biomass to increase in the greenhouse experiment. The biochar treatments however caused shifts in microbial communities (visualized by principal component analysis). We concluded that the shifts in the microbial community structure are an indirect rather than a direct effect and depend on soil conditions and nutrient status.
\end{abstract}

Key words: biochar, PLFAs, soil microbial communities, temperate soil

\section{Introduction}

Biochar is the solid residue obtained after the pyrolysis of organic material under the exclusion of oxygen. Biochar as a soil amendment has become an important topic in soil science in the past few years, and many research groups are studying the effects of biochar on (agro) ecosystems. The investigations tackle issues such as carbon sequestration, reduction of greenhouse gas emissions, regeneration of degraded soils, biochar as a possible nutrient carrier for better plant growth and enhancement of microbial proliferation.

Terra preta is the oldest documented form of biochar amendment in soils. In these Anthrosols in the Amazon region, biochar was found to enhance microbial growth compared to the same soil without biochar (Grossman et al. 2010). Moreover, the biomass of the bacterial community in this soil was higher and more diverse (O'Neill et al. 2009). In temperate Australian soils, biochar (650-1600 years old) improved soil fertility (Downie et al. 2011).

Biochar is resistant to degradation in soil (Masek et al. 2011 and Watzinger et al. 2013). Its addition to soil may influence microorganisms directly by being metabolized and acting as a major C source. Ameloot et al. (2013) listed several studies that indicate assimilation and plant uptake of $\mathrm{N}$ from labeled biochar or increased soil respiration rates after biochar amendment. For example Zimmerman (2010) found a doubled mineralization rate of biochar in the presence of microorganisms. 
Physical and chemical parameters of the soil indirectly cause shifts in microbial abundance (Pietikäinen et al. 2000, Liang et al. 2010, Kolb et al. 2009) and structure (Lehmann et al. 2011, Glaser and Birk 2012, Watzinger et al. 2013, Farrell et al. 2013). Kolton et al. (2011) reported that biochar induced shifts in bacterial communities often occur at the genus level (e.g. Flavobacterium sp.) and that the promotion of certain bacterial genera could at least partially explain the induced growth and plant resistance phenomena. The $\mathrm{pH}$-value is a key soil parameter (Brewer et al. 2011). Adding fresh, untreated biochar to soil usually increases the soil pH-value. The degree of change in these values depends on factors such as pyrolysis temperature, feedstock of biochar, degree of oxidation and the current pH of the soil (Lehmann et al. 2011, Lehmann et al. 2006, Chan and Xu 2009, Cheng et al. 2006). Not all microorganisms react similarly to a $\mathrm{pH}$-increase. Fungi have higher biomass in acidic soils, whereas actinomycetes avoid this environment and prefer soils with high pH-values (Giri et al. 2005). It is possible to increase the water retention capacity by adding biochar, thus increasing the suitability of amended soils as microbial habitat (Glaser et al. 2002). Especially in sandy soils, the biochar micropores and surface structure cause a potential retention effect. In case of soil dehydration, biochar can offer retreat areas for microorganisms (Schimel et al. 2007).

The production type and amendment method of biochar can also indirectly influence microorganism communities. Steinbeiss et al. (2009) discovered that the biochar type determined which groups of microorganisms were involved in decomposition processes. Furthermore, the pores in biochar can be valuable microhabitats for microorganisms (Downie et al. 2009) and could act as a safe refuge from predators (Pietikäinen et al. 2000). Nonetheless, there is no quantitative proof for the protective characteristics of biochar (Lehmann et al. 2011). Note also that the average pore size of biochars ( $\mathrm{nm}$ scale) is much smaller than that of the smallest soil organisms ( $\mu \mathrm{m}$ scale) (Ameloot et al. 2013). Nonetheless, the sorption of easily degradable organic compounds, dissolved organic carbon (DOC) and chemisorption of ammonium $\left(\mathrm{NH}_{4}^{+}\right)$(Anderson et al. 2011) at biochar surfaces due to the presence of functional groups, could indicate its suitability as a favorable habitat (Pietikainen et al. 2000). The pore size and the internal surface structure of biochar depend on the feedstock (Abit et al. 2012). The feedstock of biochar has an important impact on the soil microbial response to amendment in soil. Ameloot et al. (2013) reported that the greater the lignin content, the aromatic $\mathrm{C}$ content and the $\mathrm{C} / \mathrm{N}$ ratio of feedstock of the resulting biochar, the smaller the biochar mineralization rate. Apart from the feedstock, the pyrolysis temperature seems to be a key factor in manipulating biochar characteristics. High pyrolysis temperatures increase the micro-porosity and fractioning of biochar structure. Also, the stable components in biochar increase, while the labile components decrease with high pyrolysis temperature. The stable parts remain in the soil for a long time, whereas the labile parts are available to the microorganisms (Abit et al. 2012, Mašek et al. 2011, Lehmann et al. 2011). Volatile organic compounds (VOCs) were also found in the labile fractions and these substances might affect microorganisms (Lehmann et al. 2011, Deenik et al. 2011, Kloss et al. 2013).

Spokas et al. (2012) listed yield results from many biochar studies: to date no definitive answer has been found for whether biochar causes positive or negative effects in agricultural soil beyond $\mathrm{C}$ sequestration. Growing attention is being given to biochar amendment in soil and its impact on soil microbial communities. Lehmann et al. (2011) reviewed the impacts of biochar on soil communities. Quilliam et al. (2012) determined the level of microbial colonization of wood-derived biochar that had been buried in an agricultural soil for three years. They suggested that, over the short term ( 3 years) biochar does not provide a significant habitat for soil microbes. Ameloot et al. (2013) reviewed how soil micro-, meso- and macroorganisms interact with biochar stability, they also evaluated C content, feedstock and pyrolysis conditions, application rates, native SOC contents and soil chemical properties as factors involved in these interactions.

In a short term experiment Farrell et al. (2013) determined, using two biochars amended in acridic arenosol, a rapid incorporation of labelled ${ }^{13} \mathrm{C}$ in microbial PLFAs. They assumed that the shifts and changes in microbial community reflected the varying utilisation of biochar-C.

In the present study the effect of biochar on the native soil microbial communities in temperate soil were targeted. The aim was to answer the following questions: What influence does biochar have on the microbial communities in soil and what are the reasons for it? The investigations have focused on different aspects: type of biochar, soil and application rate. To answer these questions we set up a greenhouse experiment and a field experiment with different biochar types on contrasting soils. This enables us to analyze the reactions of microbial communities to different biochar-soil environments. 


\section{Materials and methods}

\section{Soil and biochar characterization}

For the experimental set-up, three Austrian agricultural soils were selected. The soils were a sandy Planosol from Eschenau, a calcareous Chernozem (on loess) from Traismauer, both Lower Austria, and a gleyic Cambisol from Kaindorf/Obertiefenbach (Styria). The soil from Eschenau is an acidic sandy soil with low nutrient retention capacity. The soil of Traismauer, in contrast, is a calcareous, silty soil with high capacity to retain nutrients. The gleyic Cambisol of Kaindorf is characterized by relatively high clay content (Table 1). For all soils, the pH-value, electric conductivity (EC) and the cation exchange capacity (CEC) were determined by standard methods (see Appendix). Carbonate carbon content $\left(\mathrm{C}_{\text {inorg }}\right)$, soil organic carbon content $\left(\mathrm{C}_{\text {org }}\right)$ and nitrogen $(\mathrm{N})$ were determined according to standard methods (supplementary information). Particle size was determined with a sedigraph based on a modified standard method (supplementary information). Soil material from the topsoil (Ap-horizon, $0-20 \mathrm{~cm}$ ) was excavated in summer 2009. After transport to the greenhouse, the soil materials were air-dried and stored until the experiment.

Table 1. Soil characteristics

\begin{tabular}{|c|c|c|c|}
\hline & Eschenau & Traismauer & Kaindorf \\
\hline GPS coordinates & $\begin{array}{c}\mathrm{N} 48^{\circ} 46^{\prime} 32.9^{\prime \prime} ; \\
\mathrm{E} 15^{\circ} 14^{\prime} 28.6^{\prime \prime}( \pm 2.4 \mathrm{~m})\end{array}$ & $\begin{array}{c}\text { N 48 } 18^{\circ} 52.6^{\prime \prime} ; \\
\text { E } 15^{\circ} 44^{\prime} 20.5^{\prime \prime}( \pm 4 \mathrm{~m})\end{array}$ & $\begin{array}{c}\text { N 471' } 46.0^{\prime \prime} \\
\text { E } 15^{\circ} 50^{\prime} 40.6^{\prime \prime}( \pm 4 \mathrm{~m})\end{array}$ \\
\hline soil type & Planosol & Chernozem & Cambisol \\
\hline Texture & sandy loam & silt loam & clay loam \\
\hline $\mathrm{EC}\left(\mu \mathrm{S} \mathrm{cm} \mathrm{cm}^{-1}\right)$ & $41.2 \pm 12.3$ & $173.6 \pm 5.2$ & $103.9 \pm 0.1$ \\
\hline $\mathrm{CEC}\left(\mathrm{mmol}_{\mathrm{c}} \mathrm{kg}^{-1}\right)$ & $75.1 \pm 0.4$ & $208.6 \pm 3.6$ & $209.4 \pm 2.2$ \\
\hline $\mathrm{pH}$-value $\left(\mathrm{CaCl}_{2}\right)$ & $5.4 \pm 0.0$ & $7.4 \pm 0.1$ & $6.6 \pm 0.1$ \\
\hline $\mathrm{C}_{\text {inorg }}-$ content (\%) & $0 \pm 0.0$ & $1.90 \pm 0.0$ & $0 \pm 0.0$ \\
\hline $\mathrm{C}_{\text {org }} \%$ & $1.6 \pm 0.0$ & $1.5 \pm 0.0$ & $2.36 \pm 0.0$ \\
\hline $\left.\mathrm{N}_{\text {tot }(} \%\right)$ & $0.11 \pm 0.01$ & $0.13 \pm 00.01$ & $0.17 \pm 0.01$ \\
\hline previous crop 2010 & rye (Secale cereale) & alfalfa (Medicago sativa) & wheat (Triticum aestivum) \\
\hline $\begin{array}{l}\rho_{\mathrm{B}}\left(\mathrm{g} \mathrm{cm}^{-3}\right) \\
\text { greenhouse }\end{array}$ & $1.22-1.39$ & $1.14-1.32$ & 1.24 \\
\hline $\begin{array}{l}\text { WHC (g/100g) } \\
\text { greenhouse }\end{array}$ & $37.1\left(\rho_{\mathrm{B}}=1.22 \mathrm{~g} \mathrm{~cm}^{-3}\right)$ & $38.8\left(\rho_{B}=1.14 \mathrm{~g} \mathrm{~cm}^{-3}\right)$ & $45\left(\rho_{B}=1.24 \mathrm{~g} \mathrm{~cm}^{-3}\right)$ \\
\hline
\end{tabular}

$\mathrm{EC}=$ electrical conductivity, $\mathrm{CEC}=$ cation exchange capacity, $\mathrm{C}_{\text {inorg }}=$ carbonate content, $\mathrm{C}_{\text {org }}=$ soil organic carbon content, $\mathrm{N}_{\text {tot }}=$ total nitrogen content, $\rho_{B}=$ bulk density in the greenhouse experiment, $W H C=$ water holding capacity of the greenhouse experiment.

In the greenhouse experiment three different feedstocks were used for biochar production, vineyard pruning $\left(525^{\circ} \mathrm{C}\right)$, wheat straw $\left(525^{\circ} \mathrm{C}\right)$, and a woodchip-mixture $\left(525^{\circ} \mathrm{C}\right)$. Additionally vineyard pruning biochar was produced using a lower pyrolysis temperature of $400^{\circ} \mathrm{C}$ (Table 2). The different feedstocks for pyrolysis were selected according to their local availability as residues from agricultural crop production and forestry. The main differences were expected between straw and woody biomass materials. The different woody materials might also have caused different biochar properties because of differences in porosity and ligno-cellulosic characteristics. Vineyard pruning was an important feedstock because of the abundant availability in the region of one of the field experiments. Therefore a pyrolysis temperature comparison was made with this material.

To guarantee complete pyrolysis, each feedstock was given a different dwell time. The vineyard pruning biochar was pyrolysed at a heating rate of $2^{\circ} \mathrm{C} \mathrm{min}-1$ with a dwell time of $6 \mathrm{~h}$ at $525^{\circ} \mathrm{C}$ and $8 \mathrm{~h}$ at $400^{\circ} \mathrm{C}$ at the laboratory of AIT. The wheat straw and woodchip-mixture biochars were produced at a rotary kiln in Dürnrohr (Austria; EVN) each at a pyrolysis temperature of $525^{\circ} \mathrm{C}$, dwell times of approximately $1 \mathrm{~h}$, and heating rates of $10-20^{\circ} \mathrm{C} \mathrm{min}-1$. Argon ( $\mathrm{Ar}$ ) was constantly flushed during the whole pyrolysis process to maintain the oxygen free environment inside the furnace. Biochar was ground and sieved to a particle size of $<2 \mathrm{~mm}$ for mixing with the soil ( $3 \mathrm{w} / \mathrm{w} \%$ of biochar was added to the soils). For the field experiment a commercially available biochar with $80 \%$ beech and $20 \%$ diverse hard woods (without oak), produced by SCRom Char SRL, 537265 Sincraieni (Romania) was used. The biochar was produced under normal atmosphere pressure conditions. The pyrolysis temperature was $500^{\circ} \mathrm{C}$ and the dwell time was $2 \mathrm{~h}$. After carbonization the biochar was moistened with $20 \%$ water. 


\begin{tabular}{|c|c|c|c|c|c|}
\hline & \multicolumn{4}{|c|}{ Greenhouse } & \multirow{2}{*}{$\begin{array}{c}\text { Field } \\
\text { ROMCHAR } \\
\text { 80\%beech, } \\
20 \% \text { other hard } \\
\text { wood }\end{array}$} \\
\hline & $\begin{array}{l}\text { wood } \\
\text { mixture }\end{array}$ & straw & $\begin{array}{l}\text { vineyard } \\
\text { pruning }\end{array}$ & vineyard pruning & \\
\hline pyrolysis temperature $\left({ }^{\circ} \mathrm{C}\right)$ & 525 & 525 & 525 & 400 & 500 \\
\hline heating rate $\left({ }^{\circ} \mathrm{C} \mathrm{min}^{-1}\right)$ & $10-20$ & $10-20$ & 2 & 2 & \\
\hline dwell time (h) & 1 & 1 & 6 & 8 & 2 \\
\hline $\mathrm{EC}\left(\mathrm{mS} \mathrm{cm} \mathrm{cm}^{-1}\right)$ & $1.6 \pm 0.0$ & $5.2 \pm 0.1$ & $1.1 \pm 0.0$ & $1.5 \pm 0.0$ & \\
\hline $\mathrm{CEC}\left(\mathrm{mmol}_{\mathrm{c}} \mathrm{kg}^{-1}\right)$ & $93.0 \pm 1.9$ & $148.5 \pm 0.8$ & $78.8 \pm 1.4$ & $123.5 \pm 1.3$ & \\
\hline $\mathrm{pH}$-value $\left(\mathrm{CaCl}_{2}\right)$ & $8.9 \pm 0.1$ & $9.7 \pm 0.0$ & $8.8 \pm 0.1$ & $8.3 \pm 0.0$ & \\
\hline $\mathrm{C}_{\text {tot }}(\%)$ & $67.1 \pm 1.3$ & $56.3 \pm 2.4$ & $73.1 \pm 0.9$ & $69.3 \pm 0.2$ & 72.7 \\
\hline $\mathrm{N}_{\text {tot }}(\%)$ & $1.2 \pm 0.03$ & $0.9 \pm 0.03$ & $1.3 \pm 0.03$ & $1.3 \pm 0.06$ & 0.4 \\
\hline ash content (\%) & 15.2 & 28.1 & 7.7 & 4.3 & 15.2 \\
\hline BET- $\mathrm{N}_{2}$ SA $\left(\mathrm{m}^{2} \mathrm{~g}^{-1}\right)$ & $26.41 \pm 1$ & $12.26 \pm 1$ & $4.85 \pm 0$ & $1.69 \pm 0$ & \\
\hline
\end{tabular}

$\mathrm{EC}=$ electrical conductivity, $\mathrm{CEC}=$ cation exchange capacity, $\mathrm{C}_{\text {tot }}=$ total carbon content, $\mathrm{N}_{\text {tot }}=$ total nitrogen content, $\mathrm{BET}-\mathrm{N}_{2} \mathrm{SA}=\mathrm{Brunauer}-$ Emmett-Teller specific surface area ( $\mathrm{N}_{2}$ adsorption).

\section{Greenhouse experiment}

The greenhouse experiment was conducted in October 2010, with five replicates per treatment (Table 3). The pots were $23.5 \mathrm{~cm}$ in diameter and $40 \mathrm{~cm}$ in height. To collect seepage water the pots had a drainage outlet to which a flexible siphon-like tube was fixed. The pots were filled (from bottom to top) with $15 \mathrm{~mm}$ coarse sand $(0.5-2 \mathrm{~mm}$ ), $15 \mathrm{~mm}$ fine sand $(0.4-0.8 \mathrm{~mm})$ and $350 \mathrm{~mm}$ soil-biochar mixture; bulk density was approximately $1.3 \mathrm{~g} \mathrm{~cm}^{-3}$. A soil moisture probe was installed in one pot per treatment. Water holding capacity (WHC) was measured gravimetrically from disturbed soil samples. For monitoring the moisture content in the pots we used a TDR measurement system: Trase multiplex system $16050 X 1$ (Soil moisture equipment corp., Santa Barbara, USA), and Echo probes 10 HS (Decagon Devices, Inc., WA, USA).

Table 3. Treatments used in the greenhouse experiment

\begin{tabular}{|c|c|c|c|c|c|}
\hline $\begin{array}{l}\text { treatment } \\
\text { code }\end{array}$ & soil origin & biochar & $\begin{array}{c}\text { pyrolysis } \\
\text { temperature } \\
\left({ }^{\circ} \mathrm{C}\right)\end{array}$ & $\begin{array}{l}\text { amount } \\
\text { of } \\
\text { biochar } \\
(\% \mathrm{w} / \mathrm{w})\end{array}$ & $\begin{array}{l}\text { Nitrogen } \\
\text { fertilizer } \\
\left(\mathrm{kg} \mathrm{ha}^{-1}\right)\end{array}$ \\
\hline E_WN & Eschenau & wood & 525 & 3 & 100 \\
\hline E_SN & Eschenau & straw & 525 & 3 & 100 \\
\hline E_VN400 & Eschenau & $\begin{array}{l}\text { vineyard } \\
\text { pruning }\end{array}$ & 400 & 3 & 100 \\
\hline E_VN & Eschenau & $\begin{array}{l}\text { vineyard } \\
\text { pruning }\end{array}$ & 525 & 3 & 100 \\
\hline E_W & Eschenau & wood & 525 & 3 & 0 \\
\hline$E$ & Eschenau & none & - & 0 & 0 \\
\hline$E_{-} N$ & Eschenau & none & - & 0 & 100 \\
\hline K_WN & Kaindorf & wood & 525 & 3 & 100 \\
\hline K_N & Kaindorf & none & - & 0 & 100 \\
\hline T_WN & Traismauer & wood & 525 & 3 & 100 \\
\hline T_N & Traismauer & none & - & 0 & 100 \\
\hline
\end{tabular}


In the pots, a crop rotation with mustard (Sinapis alba L.cv. 'Serval'; 50 seedlings per pot, density of $3 \mathrm{~g} \mathrm{~m}^{-2}$ ), barley (Hordeum vulgare L. cv. 'Xanadu'; ten seedlings per pot) and red clover (Trifolium pratense L. cv. 'ReichersbergerNeu'; six seedlings per pot) was grown. Soil was sampled on day 2, 4, 7, 14, 24 (2 days after fertilization), 51 ( 2 days after fertilization, shooting of barley), 80 (maturation of barley) and 109 (harvest) and 297 (32 days after planting clover). The whole timeline of sampling and soil treatment is shown in Figure 1 . Soil samples were taken with a soil auger $(\varnothing=25 \mathrm{~mm})$ out a depth between 15 and $20 \mathrm{~cm}$ with a distance to pot side of $40 \mathrm{~mm}$. Samples were filled into a plastic bags and frozen at $-10^{\circ} \mathrm{C}$. The standard fertilizer rate was $40 \mathrm{~kg} \mathrm{~N}$ ha ${ }^{-1}$ for mustard and $100 \mathrm{~kg} \mathrm{~N} \mathrm{ha}^{-1}$ (N100) for barley, using a commercial combination fertilizer ( $\mathrm{N}: \mathrm{P}_{2} \mathrm{O}_{5}: \mathrm{K}_{2} \mathrm{O}: \mathrm{S}=15: 15: 15: 3$; Linzer Star). Irrigation was conducted according to the measured water content using artificial rain water ( $3 \mathrm{mg} \mathrm{Ca} \mathrm{l}^{-1}: 50 \%$ of $\mathrm{Ca}$ was added as $\mathrm{CaCl}_{2} \times 2 \mathrm{H}_{2} \mathrm{O}, 50 \%$ as $\mathrm{CaSO}_{4} \times 2 \mathrm{H}_{2} \mathrm{O}$ ). At certain time intervals, excess irrigation was conducted in order to trigger leaching. The $\mathrm{C}$ and $\mathrm{N}$ content from soil was measured in parallel to the PLFA soil samplings at day 0, day 51, day 170 and day 297 by an elemental analyzer after grinding the samples (CHNS-O EA 1108; Carlo Erba Instruments, Milano, Italy). Seepages were collected at intervals of approximately four weeks and analyzed for $\mathrm{pH}, \mathrm{EC}$, ammonium- $\mathrm{N}\left(\mathrm{NH}_{4}^{+}\right)$, nitrate-N $\left(\mathrm{NO}_{3}{ }^{-}\right)$and dissolved organic carbon (DOC) (Bücker 2012). Seepage data were tested for correlation with the PLFA data. Plants were harvested and analyzed for dry matter yield and elemental composition (Kloss et al. 2013); the dry matter yield data were tested for correlation with the PLFA data.
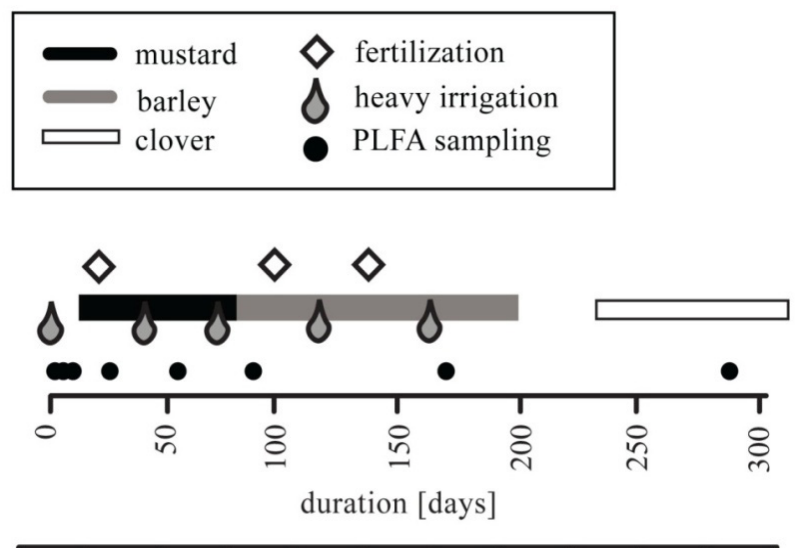

\begin{tabular}{|c|c|c|c|c|c|c|c|c|c|c|c|}
\hline & $T$ & T & $\mathrm{T}$ & T & 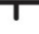 & $T$ & $T$ & T & $T$ & T & $\mathbf{I}$ \\
\hline$\stackrel{ }{\circ}$ & $\stackrel{0}{0}$ & & $=$ & $=$ & $=$ & $\exists$ & - & - & $=$ & $=$ & 工 \\
\hline ్․ & $\stackrel{\mathrm{N}}{\mathrm{N}}$ & ల) & 으 & 기 & ㄱ. & 이 & ㄱ. & $\overline{0}$ & 으 & $\overline{\mathrm{N}}$ & $\overline{\mathrm{N}}$ \\
\hline $\begin{array}{l}\text { z } \\
\text { Z }\end{array}$ & ญ्ঠ & స్త్ & बे & $\sum^{\tilde{J}}$ & $\frac{\grave{2}}{4}$ & $\vec{J}^{\mathrm{J}}$ & $\Xi$ & $\frac{N}{\Xi}$ & $\stackrel{00}{2}$ & \& & 0 \\
\hline
\end{tabular}

Fig. 1. Schematic timeline of sampling, fertilization and irrigation days of the greenhouse experiment (heavy irrigation was performed at certain times to generate seepage water). Cultivated plants were mustard (Sinapis alba L.cv. 'Serval'; 50 seedlings per pot, density of 3 $\mathrm{g} \mathrm{m}^{-2}$ ), barley (Hordeum vulgare L. cv. 'Xanadu'; ten seedlings per pot) and red clover (Trifolium pratense L. cv. 'ReichersbergerNeu'; six seedlings per pot); the gap between barley and clover cultivation shows the state of a fallow period.

\section{Field experiment}

To study the behavior and carbon sequestration of biochar under field conditions, we established field experiments at two sites. We selected the locations "Traismauer" and "Kaindorf" as experimental sites because they were adjacent to the places where we collected the soil samples for the greenhouse experiment. Biochar application was carried out in March 2011. On both field sites, 3 biochar treatments and a control plot with four replicates each (16 plots per location) were established. The four treatments consisted of soil amended with (i) $3 \%$ biochar without any fertilizer (BC3), (ii) 1\% biochar with NPK-fertilization (BC1NPK), (iii) 3\% biochar with NPK-fertilization (BC3NPK) and (iv) no biochar but NPK-fertilization (NPK). Fertilizer amount was adapted for each crop. Corn was cultivated in Traismauer in 2011 and winter wheat was the subsequent crop in the PLFA sampling year 2012. At the PLFA soil sampling day, the wheat was nearly fully matured (June 2012). In Kaindorf the cultivation in 2011 was spring barley and in the PLFA sampling year 2012 sunflower; at PLFA sampling day the sunflower was in the juvenile growth phase (May 2012). Each plot was circular with a diameter of $6.5 \mathrm{~m}$. Soil samples were taken from the center of the plots, corresponding to a circle with a diameter of $3.5 \mathrm{~m}$. The plots were arranged according to a Latin square with $n=4$. 
Table 4. Field experiment treatments. $\mathrm{P}$ and $\mathrm{K}$ fertilizer level was identical for all plots.

\begin{tabular}{|c|c|c|c|c|}
\hline $\begin{array}{l}\text { treatment } \\
\text { code }\end{array}$ & location & $\begin{array}{c}\text { biochar } \\
\text { application }\end{array}$ & $\begin{array}{l}\text { crop rotation } \\
(2011 / 2012)\end{array}$ & $\begin{array}{l}\mathrm{N} \text { application rate } \\
\left(\mathrm{NH}_{4} \mathrm{NO}_{3} \mathrm{~kg} \mathrm{ha}^{-1}\right)\end{array}$ \\
\hline $\mathrm{BC} 3$ & Kaindorf & $72 \mathrm{Mg} \mathrm{ha}^{-1}$ & corn / wheat & $0 / 0$ \\
\hline BC1NPK & Kaindorf & $24 \mathrm{Mg} \mathrm{ha}^{-1}$ & corn / wheat & $150 / 120$ \\
\hline BC3NPK & Kaindorf & $72 \mathrm{Mg} \mathrm{ha}^{-1}$ & corn / wheat & $150 / 120$ \\
\hline NPK & Kaindorf & - & corn / wheat & $150 / 120$ \\
\hline $\mathrm{BC} 3$ & Traismauer & $72 \mathrm{Mg} \mathrm{ha}^{-1}$ & barley / sunflower & $0 / 0$ \\
\hline BC1NPK & Traismauer & $24 \mathrm{Mg} \mathrm{ha}^{-1}$ & barley / sunflower & $120 / 100$ \\
\hline BC3NPK & Traismauer & $72 \mathrm{Mg} \mathrm{ha}^{-1}$ & barley / sunflower & $120 / 100$ \\
\hline NPK & Traismauer & - & barley / sunflower & $120 / 100$ \\
\hline
\end{tabular}

\section{Analysis of phospholipid fatty acids (PLFAs)}

Microorganisms were investigated using phospholipid fatty acids (PLFAs) analyses. PLFAs were extracted from soil samples according to the procedure of Bligh and Dyer (1959) as described by Frostegård et al. (1991). We used $2 \pm 0.2 \mathrm{~g}$ soil for each sampling extraction. Details on the extraction and measuring method used are provided in Watzinger et al. (2013). We analyzed 25 PLFAs which we arranged in five groups of PLFAs. The interpretation of PLFA biomarkers was modified after Paul and Clark (1996): Gram positive bacteria (i14:0, i15:0, a15:0, i16:0, a17:0, i17:0 (Brennan 1988)), actinomycetes (10Me16:0, 10Me17:0, 10Me18:0, 12Me18:0 (White and MacNaughton

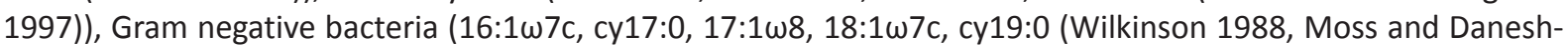

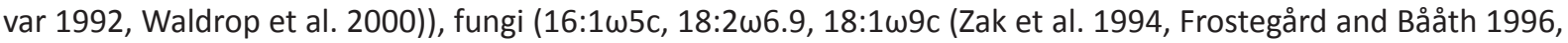
Olsson et al. 1995)) and unspecific fatty acids (14:0, 15:0, 16:1w6c, 16:0, 17:0, 18:0, 19:1). Identification of microbial groups based on different fatty acids is problematic as pointed out by Frostegård et al. (2011). The grouping of PLFAs in this study is more a theoretical instrument than a fixed categorisation of microorganism groups. For these reason we used a single representative PLFA from each group and not the sum of many PLFAs, this also allows an interpretation without a connection to given microbial groups.

\section{Statistical analysis}

All analytical results were calculated on the basis of oven-dry $\left(105^{\circ} \mathrm{C}\right)$ weight of soil. Statistical evaluation was performed with SPSS 19.0 for Windows; curve fitting was obtained by SigmaPlot 10.0 for Windows. Data were tested with the Dixon Q-Test for outliers, detected outliers were deleted. Data showed a normal distribution of PLFAs within the different treatments. A Principal Component Analysis (PCA) was performed on data to reduce PLFAs from 25 to a few major factors; the deleted outliers were replaced by SPSS through means. PCA was separately analyzed for each sampling day. Based on the principal component factors a MANOVA was performed for each sampling day. Post-Hoc Turkey's test was performed, significance was accepted at $p<0.05$. In Table 5 different letters indicate significant difference within one column ( $p<0.05$ Turkey's test). PCA was also used to visualize the separation of treatments or soils. In the figures we illustrated the principal component factors which were significantly affected to visualize separation of treatments. In the glasshouse experiment we analyzed the difference of seven treatments within the soil of Eschenau. Additionally, the treatments wood biochar with fertilizer (WN) and soil with fertilizer but without biochar (N) were compared from the soils of Eschenau, Kaindorf and Traismauer. For the field experiment, four different treatments were analyzed and compared (Kaindorf and Traismauer).

Finally, a correlation for the glasshouse experiment was done separately for each soil with biochar and without biochar. We calculated the mean PLFA amounts from each treatment and analyzed individual PLFAs with the factors of soil characteristics ( $\mathrm{N}$-content, $\mathrm{C}$-content, $\mathrm{C} / \mathrm{N}$ ratio, water content), seepage composition ( $\mathrm{pH}$-value, DOC, ammonium, nitrate, electric conductivity, sulphate) and plant performance (weight of dried plant material) with the Spearman correlation (=S.c.). The PLFAs considered were: i14:0, 14:0, i15:0, a15:0, 15:0, i16:0, 16:1w7c,

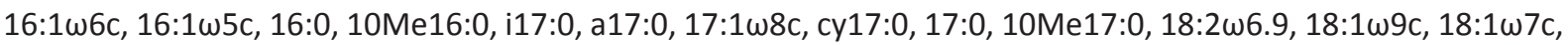
18:0, 10Me18:0, 12Me18:0, су19:0, 19:1. 


\section{Results \\ Greenhouse experiment}

The temporal development of total PLFA concentrations, an indicator of microbial biomass is shown in Figure 2 . The total PLFAs showed no significant difference, but differences occurred between soils. The first ten days included 4 sampling days (days $0,2,5$ and 10). In this initial phase, the microbial community showed high sums but chaotic trends. After the fourth sampling date, the sampling intervals were extended to one month or more. The microbial community in the Eschenau soil showed an increasing trend in PLFA concentrations until day 86 . The treatment E_VN400 even showed an increase until day 170, whereas in the other treatments the PLFA sum slowly declined from day 86. The concentrations in the soils from Kaindorf and Traismauer developed similarly, but with a wider range. In both soils, the PLFA sums of treatments with biochar were slightly lower compared to the controls.
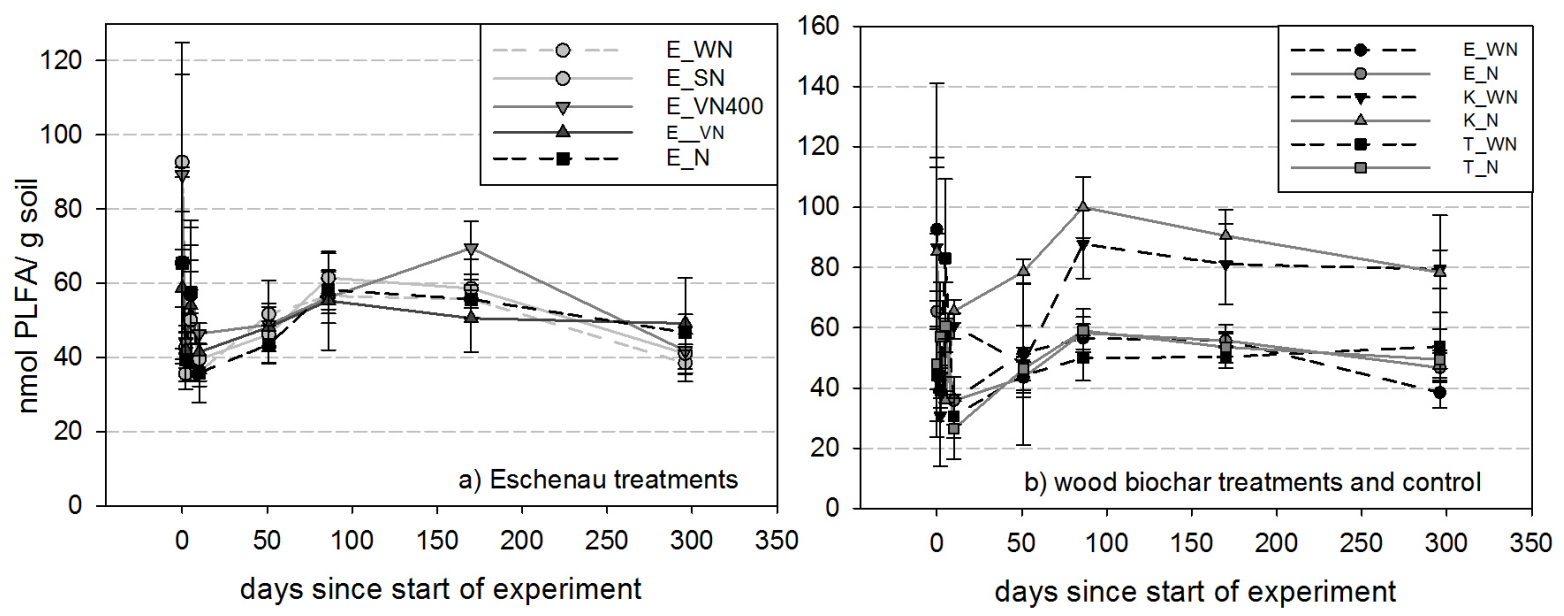

Fig. 2. Soil PLFA concentrations from the greenhouse experiment of a) different treatments for the Eschenau (E) and b) comparison of the wood biochar treatments to the control in Eschenau (E), Kaindorf $(K)$ and Traismauer $(T)$ soils. WN= wood biochar with nitrogen; $\mathrm{SN}=$ straw biochar with nitrogen, $\mathrm{VN} 400=$ vineyard pruning biochar with pyrolysis temperature $400^{\circ} \mathrm{C}$ with nitrogen; $\mathrm{VN}=$ vineyard pruning biochar with nitrogen, $\mathrm{N}=$ without biochar with nitrogen. Error bars indicate standard deviation; $\mathrm{n}=5$.

We focused on individual PLFAs but also investigated five microbial groups: Gram positive bacteria, actinomycetes, Gram negative bacteria, fungal and unspecific PLFAs. In Figure 3, the occurrence of one selected representative fatty acid for each soil microbial group: Gram positive bacteria, actinomycetes, Gram negative bacteria, fungal and unspecific PLFAs, are shown for the different soil treatments. The Gram positive bacterial PLFA a15:0 and the Gram negative bacterial PLFA cy17:0 remained largely unchanged across the whole experiment. The actinomycete PLFA 10Me18:0 increased on day 170 and 297. The saprophytic fungi biomarker PLFA 18:2w6,9 decreased over time. Unspecified PLFAs (i.e. 16:0) also decreased with time.

The PLFA analyses showed few significant trends. The MANOVA for the two treatments, wood biochar with fertilizer (WN) and soil with fertilizer but without biochar (N) from Eschenau, Kaindorf and Traismauer soils, showed differences between the three soils but no differences between treatments. In the MANOVA for the seven different treatments from the Eschnau soil the treatment E_VN400 and E_VN differed significantly from all other biochar treatments and the control treatments; in contrast E_WN and E_W differed only from the control treatments without biochar. Treatment E_VN400 showed a significant increase in concentration of individual PLFAs (Figs. 2 and 3). Generally, PLFA concentrations of Kaindorf were highest and those of Traismauer lowest. 


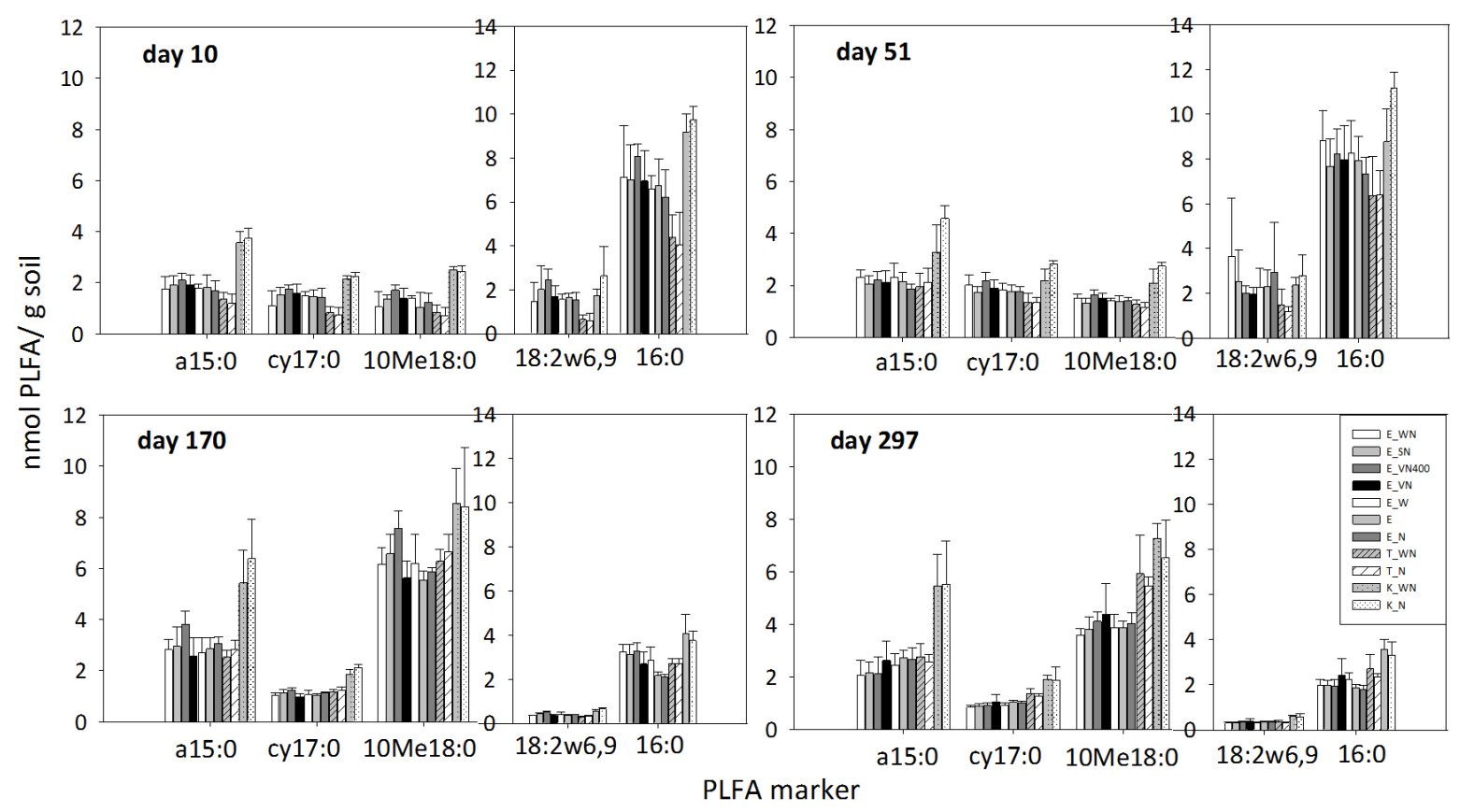

Fig. 3. Five PLFAs (a15:0, cy17:0, 10Me18:0, 18:2w6.9 and 16:0) of the studied treatments from the greenhouse experiment on four different sampling days. $\mathrm{E}=$ Eschenau; $\mathrm{T}=$ Traismauer; $\mathrm{K}=$ Kaindorf; $\mathrm{WN}=$ wood biochar with nitrogen; $\mathrm{SN}=$ straw biochar with nitrogen; VN400 = vineyard pruning biochar with pyrolysis temperature $400^{\circ} \mathrm{C}$ with nitrogen; $\mathrm{VN}=$ vineyard pruning biochar with nitrogen; $\mathrm{W}=$ wood biochar without nitrogen; $\mathrm{E}=$ without biochar without nitrogen; $\mathrm{N}=$ without biochar with nitrogen. Error bars indicate standard deviations; $\mathrm{n}=5$.

For principal component analysis we selected four sampling days. This provided insight into the microbial community shifts and into potential dominant drivers (specific PLFAs or organism groups) of these shifts. The principal component analysis of the greenhouse experiment showed a significant grouping of the treatments and clarified the results of the PLFA analysis. The Eschenau treatments showed a separation between groups of treatments with biochar and those without; especially the above-mentioned biochar treatments E_VN400 and E_VN showed a large separation on day 10 and day 51 . Later, on day 170 and day 297, only the treatments E_WN and E_W showed little separation from the control treatments (Fig. 4). The Kaindorf and Traismauer treatments showed no separation between the treatment with and without biochar (Fig. 5). This lack of separation was similar to the results from the field experiment (Fig. 7). Basically, in the treatment separation in Eschenau soil the highest influence on the grouping of treatments was shown by PLFAs belonging to the group of Gram positive bacteria (i14:0), unspecific

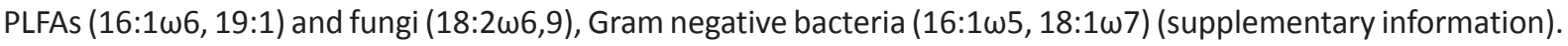
The highest influence on grouping of the wood biochar treatments and the control treatments of all three soils was shown by fungal $(16: 1 \omega 5,18: 2 \omega 6,9,18: 1 \omega 7)$ and actinomycete PLFA (10Me18:0, 12Me18:0). Nonetheless, the results showed no specific PLFAs or organism group that operated as a dominate driver of shifts. Accordingly, the separation is apparently not driven by a particular microbial group or a single PLFA.

The correlation analysis from the greenhouse experiment showed many significant correlations between PLFAs and soil properties, seepage water characterization and plant biomass (supplementary information, Tables I - III). The $\mathrm{C} / \mathrm{N}$ ratio in the soil increased after adding biochar (Table 5 ). The mean $\mathrm{C} / \mathrm{N}$ ratio from Eschenau biochar treatments increased from day $2(18)$ between days 51 and 170 , when the value was between 33 and 37 . The $\mathrm{C} / \mathrm{N}$ ratio from the Kaindorf and Traismauer treatments with biochar increased from 16 to over 20. The $\mathrm{C}$ and $\mathrm{N}$ contents were also the only parameters determined for the soil samples used for PLFA analysis. All other parameters were reported from different samples and at varying times (Kloss et al. 2013, Bücker 2012). 

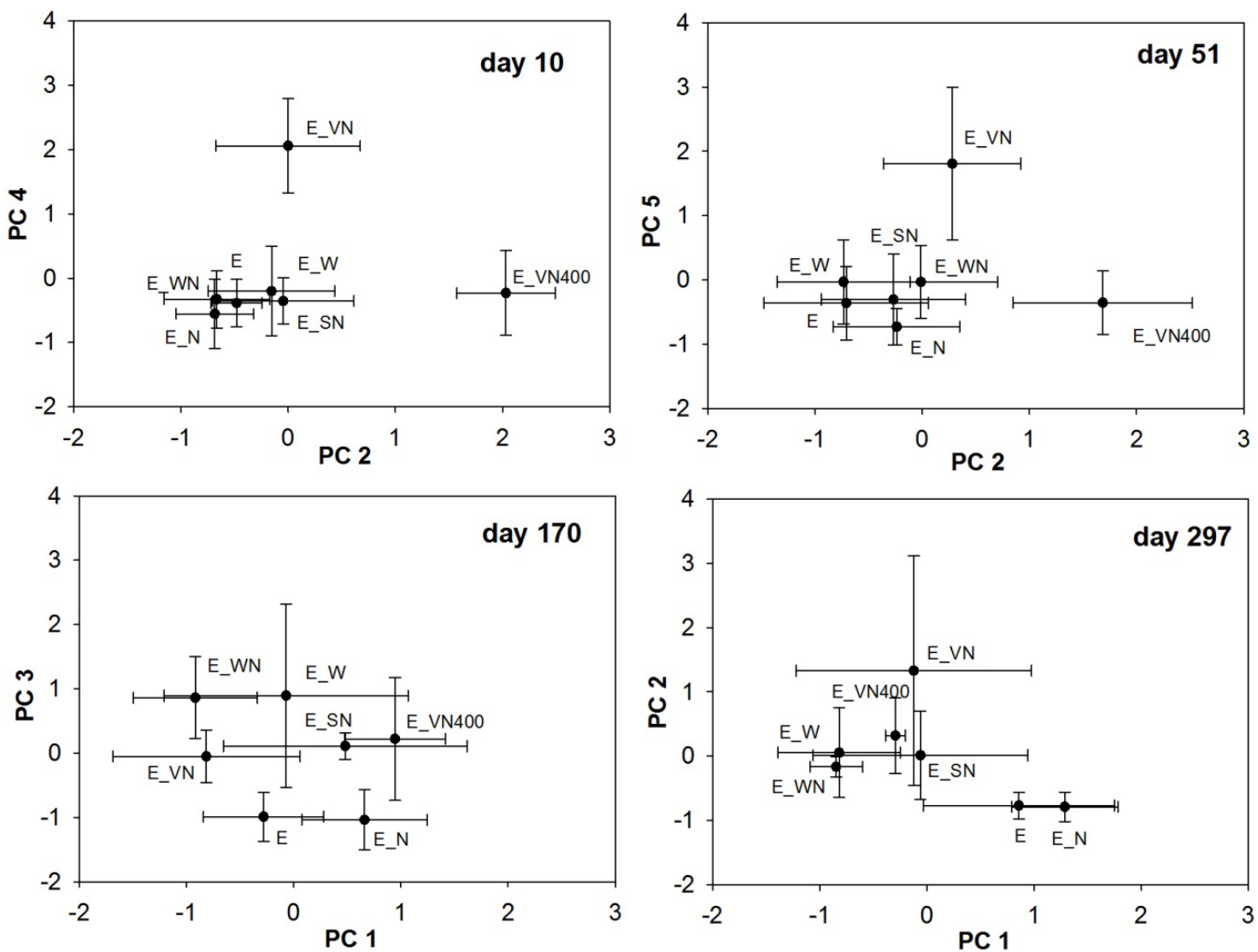

Fig. 4. Principal component analyses from the greenhouse experiment with grouping of various biochar and fertilization treatments for soil from Eschenau on four different sampling days. Error bars indicate standard deviation. E= Eschenau; WN= wood biochar with nitrogen; $\mathrm{SN}=$ straw biochar with nitrogen; VN400= vineyard pruning biochar with pyrolysis temperature $400^{\circ} \mathrm{C}$ with nitrogen; $\mathrm{VN}=$ vineyard pruning biochar with nitrogen; $\mathrm{W}=$ wood biochar without nitrogen; $\mathrm{E}=$ without biochar without nitrogen; $\mathrm{N}=$ without biochar with nitrogen. For more data on the eigenvalue and variance see supplementary information.
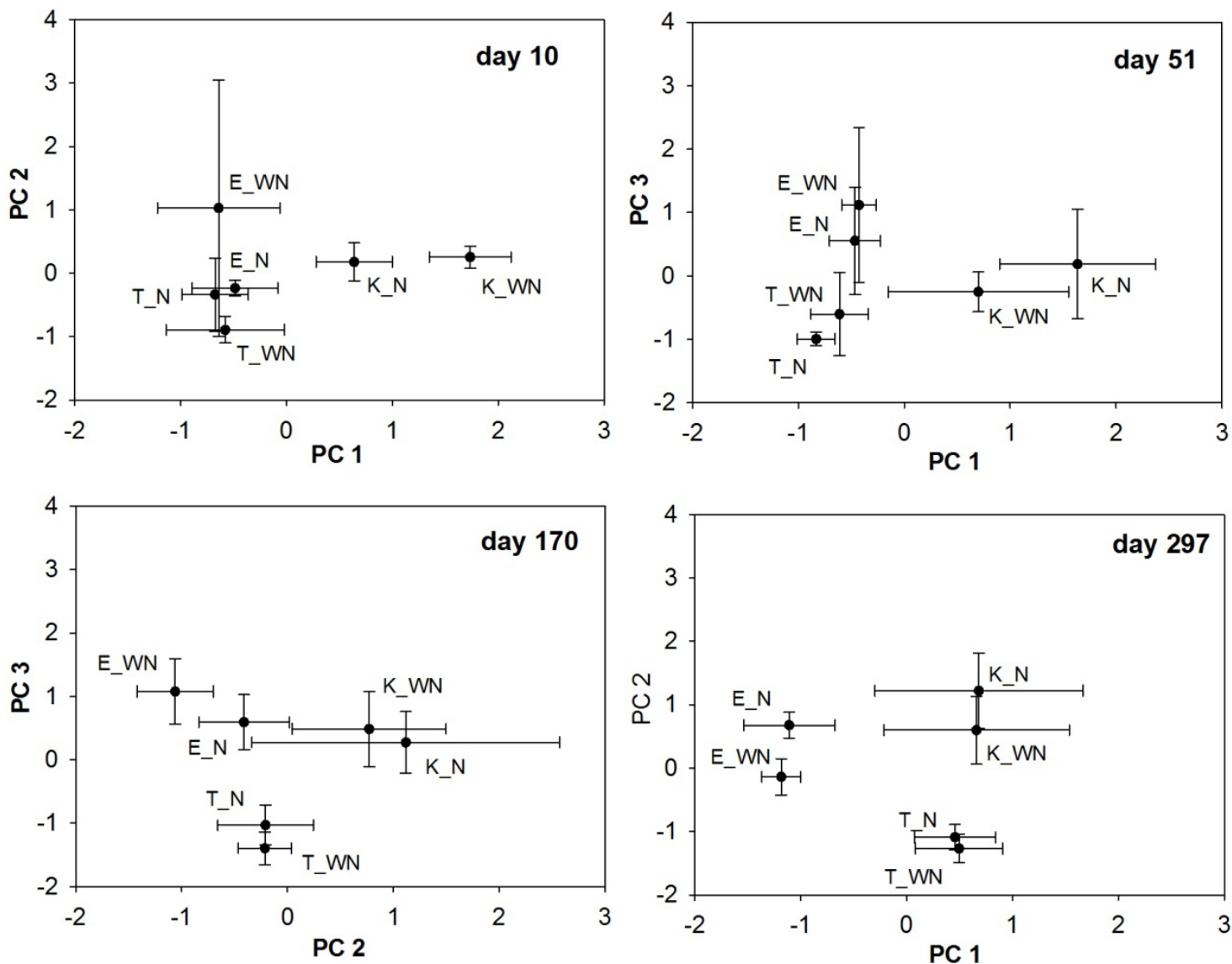

Fig. 5. Principal component analyses from the greenhouse experiment with grouping of biochar treatment for soil from Kaindorf and Traismauer on four different sampling days Error bars indicate standard deviation. E=Eschenau; T=Traismauer; K=Kaindorf; $\mathrm{WN}=$ wood biochar with nitrogen; $\mathrm{N}=$ without biochar with nitrogen. For more data on the eigenvalue and variance see supplementary information. 
Correlations between PLFAs and the N content of soil were common, but varied with soil type. PLFAs in the Eschenau soil correlated both positively and negatively with the $\mathrm{N}$ content of soil, more negatively correlation for ammonium could be found in soil with biochar, also correlation with nitrate and DOC were present only in Eschenau soil with biochar. In the Kaindorf soil generally few correlations with PLFAs were found. No correlation of PLFAs and N-contents of soil were found. Moreover, several correlations were found regarding DOC, nitrate, Ccontents of soil and $\mathrm{C} / \mathrm{N}$ ratio of soil. In the Traismauer soil the $\mathrm{N}$ content correlated with PLFAs in soil with biochar and without; additional positively correlations with ammonium were found only in soil with biochar. Many positive correlations between $\mathrm{pH}$ and PLFAs were present in the Traismauer soil and in the Eschenau soil. Other variables (sulphate, water content, EC) correlated with diverse PLFAs, but no general patterns were evident. The Eschenau soil treatments without biochar showed a strong positive correlation with all PLFAs and with the growth of mustard, barley and clover. In the treatment with biochar only the first crop (mustard) correlated with certain PLFAs from different microbial groups.

Table 5. Mean and standard deviation of $\mathrm{C}_{\text {org }}$ and $\mathrm{N}_{\text {tot }}$ in the soil on four selected days during the greenhouse experiment ( $\mathrm{n}=5$ ). Different letters indicate significant difference within one column $(p<0.05$ Tukey's test, $\mathrm{n}=55)$, unit = $(\mathrm{g} / 100 \mathrm{~g}$ dry soil).

\begin{tabular}{|c|c|c|c|c|c|c|c|c|}
\hline & \multicolumn{2}{|c|}{ Day 0} & \multicolumn{2}{|c|}{ Day 51} & \multicolumn{2}{|c|}{ Day 170} & \multicolumn{2}{|c|}{ Day 297} \\
\hline & $\mathrm{C}_{\text {org }}$ & $\mathrm{N}_{\text {tot }}$ & $\mathrm{C}_{\text {org }}$ & $\mathrm{N}_{\text {tot }}$ & $\mathrm{C}_{\text {org }}$ & $\mathrm{N}_{\text {tot }}$ & $\mathrm{C}_{\text {org }}$ & $\mathrm{N}_{\text {tot }}$ \\
\hline E_WN & $2.8 \pm 0.6^{b}$ & $0.14 \pm 0.01 \mathrm{ab}$ & $3.1 \pm 0.3^{a b c}$ & $0.20 \pm 0.04^{c d}$ & $2.8 \pm 0.4^{b c}$ & $0.08 \pm 0.03^{b c}$ & $2.8 \pm 0.4^{\mathrm{ab}}$ & $0.1 \pm 10.01 b c$ \\
\hline E_SN & $2.6 \pm 0.2^{b}$ & $0.15 \pm 0.01^{\mathrm{ab}}$ & $2.9 \pm 0.3^{a b}$ & $0.18 \pm 0.02 \mathrm{bcd}$ & $2.8 \pm 0.5^{b c}$ & $0.08 \pm 0.01 \mathrm{bc}$ & $2.6 \pm 0.4^{a b}$ & $0.09 \pm 0.01 \mathrm{abc}$ \\
\hline E_VN400 & $3.3 \pm 0.4^{b}$ & $0.17 \pm 0.01 \mathrm{abc}$ & $3.2 \pm 0.3^{a b c}$ & $0.20 \pm 0.02^{\mathrm{cd}}$ & $3.2 \pm 0.3^{\mathrm{de}}$ & $0.09 \pm 0.01$ cde & $3.1 \pm 0.2^{a b}$ & $0.11 \pm 0.01 \mathrm{bc}$ \\
\hline E_VN & $3.1 \pm 0.5^{b}$ & $0.16 \pm 0.01 \mathrm{abc}$ & $3.4 \pm 0.2^{a b c}$ & $0.17 \pm 0.00^{\mathrm{bcd}}$ & $3.5 \pm 0.2^{\mathrm{de}}$ & $0.09 \pm 0.00$ de & $3.5 \pm 0.2^{a b}$ & $0.11 \pm 0.00^{c}$ \\
\hline E_W & $2.5 \pm 0.1^{b}$ & $0.15 \pm 0.01 a b c$ & $3.1 \pm 0.8^{a b}$ & $0.16 \pm 0.00 a b c$ & $3.0 \pm 0.3^{b c d}$ & $0.08 \pm 0.01^{\mathrm{bcd}}$ & $2.8 \pm 0.4^{a b}$ & $0.10 \pm 0.01 b c$ \\
\hline$E$ & $1.1 \pm 0.1^{\mathrm{a}}$ & $0.14 \pm 0.01 a b$ & $1.1 \pm 0.1^{\mathrm{a}}$ & $0.14 \pm 0.00^{a b}$ & $1.1 \pm 0.1^{a}$ & $0.05 \pm 0.01^{a}$ & $1.4 \pm 0.9^{a}$ & $0.08 \pm 0.01^{a}$ \\
\hline E_N & $1.0 \pm 0.1^{b}$ & $0.13 \pm 0.00^{d}$ & $1.1 \pm 0.2^{\mathrm{cd}}$ & $0.13 \pm 0.00^{f}$ & $1.0 \pm 0.3^{f}$ & $0.07 \pm 0.00^{f}$ & $0.9 \pm 0.2^{b}$ & $0.09 \pm 0.02^{f}$ \\
\hline K_WN & $3.6 \pm 0.1^{c}$ & $0.25 \pm 0.00^{c}$ & $4.3 \pm 0.1^{d}$ & $0.27 \pm 0.01^{d}$ & $4.4 \pm 0.1^{g}$ & $0.21 \pm 0.02 \mathrm{~g}$ & $4.3 \pm 0.0^{a b}$ & $0.25 \pm 0.00^{d}$ \\
\hline K_N & $2.4 \pm 1.5^{a}$ & $0.25 \pm 0.06^{a}$ & $2.4 \pm 0.7^{a}$ & $0.25 \pm 0.05^{a}$ & $2.3 \pm 0.4^{a}$ & $0.22 \pm 0.01^{a}$ & $2.0 \pm 0.3^{a}$ & $0.19 \pm 0.01^{a b}$ \\
\hline T_WN & $3.3 \pm 0.3^{b}$ & $0.20 \pm 0.00^{b c}$ & $3.4 \pm 0.5^{a b c}$ & $0.21 \pm 0.02^{\mathrm{bcd}}$ & $3.3 \pm 0.2^{\text {cde }}$ & $0.13 \pm 0.00^{e}$ & $3.1 \pm 0.1^{\mathrm{ab}}$ & $0.17 \pm 0.00^{c}$ \\
\hline T_N & $1.6 \pm 0.2^{b}$ & $0.18 \pm 0.01^{d}$ & $1.6 \pm 0.1^{\mathrm{cd}}$ & $0.17 \pm 0.01^{\mathrm{e}}$ & $1.6 \pm 0.1^{b}$ & $0.13 \pm 0.01^{b}$ & $1.4 \pm 0.4^{\mathrm{a}}$ & $0.12 \pm 0.05^{\mathrm{e}}$ \\
\hline
\end{tabular}

$\mathrm{E}=$ Eschenau; $\mathrm{T}=$ Traismauer; $\mathrm{K}=$ Kaindorf; $\mathrm{WN}=$ wood biochar with nitrogen; $\mathrm{SN}=$ straw biochar with nitrogen; VN400= vineyard pruning biochar with pyrolysis temperature $400^{\circ} \mathrm{C}$ with nitrogen; $\mathrm{VN}=$ vineyard pruning biochar with nitrogen; $\mathrm{W}=$ wood biochar without nitrogen; $\mathrm{E}=$ without biochar without nitrogen; $\mathrm{N}=$ without biochar with nitrogen; $\mathrm{C}_{\text {org }}=$ soil organic carbon content, $\mathrm{N}_{\text {tot }}=$ total nitrogen content.

\section{Field experiment}

The different treatments, including various amounts of biochar and nitrogen fertilization, did not significantly alter PLFA concentrations (Fig. 6). Only the location (climate, soil, cultivation) made a significant difference. The amounts of individual PLFAs from Kaindorf were higher than those from Traismauer, except the PLFA for fungi.

The field experiment showed few significant trends in individual PLFAs, and a clear separation of groups was evident in the principal component analysis (Fig. 7). Principal component analysis and MANOVA showed no difference in treatments within the soils. The separation from soils from the field experiment (PC 2) was caused by PLFAs from the microbial group of fungi $(18: 1 \omega 7,18: 2 \omega 6,9,18: 1 \omega 5)$, whereas the separation of treatments (PC 1) was probably caused by the fertilization regime. Responsible variables were Gram positive bacterial, Gram negative bacterial, actinomycete and unspecific PLFAs (supplementary information). 


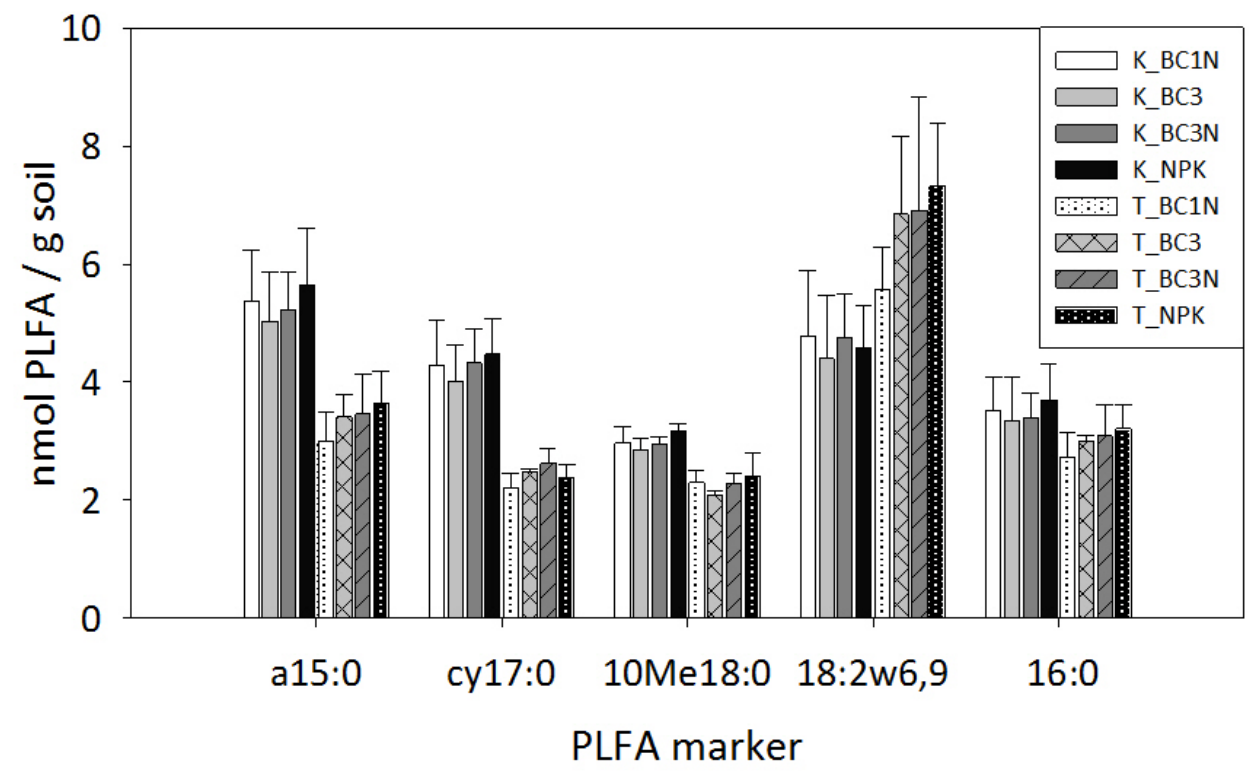

Fig. 6. Means of individual PLFAs from the field experiments at the locations Kaindorf (K) and Traismauer (T). $\mathrm{T}=$ Traismauer; $\mathrm{K}=$ Kaindorf; $\mathrm{BC} 1 \mathrm{NPK}=1 \%$ biochar with nitrogen, $\mathrm{BC} 3 \mathrm{NPK}=3 \%$ biochar with nitrogen, $\mathrm{BC}=3 \%$ biochar without nitrogen, NPK= only fertilizer; error bars indicate standard deviations; $n=5$.

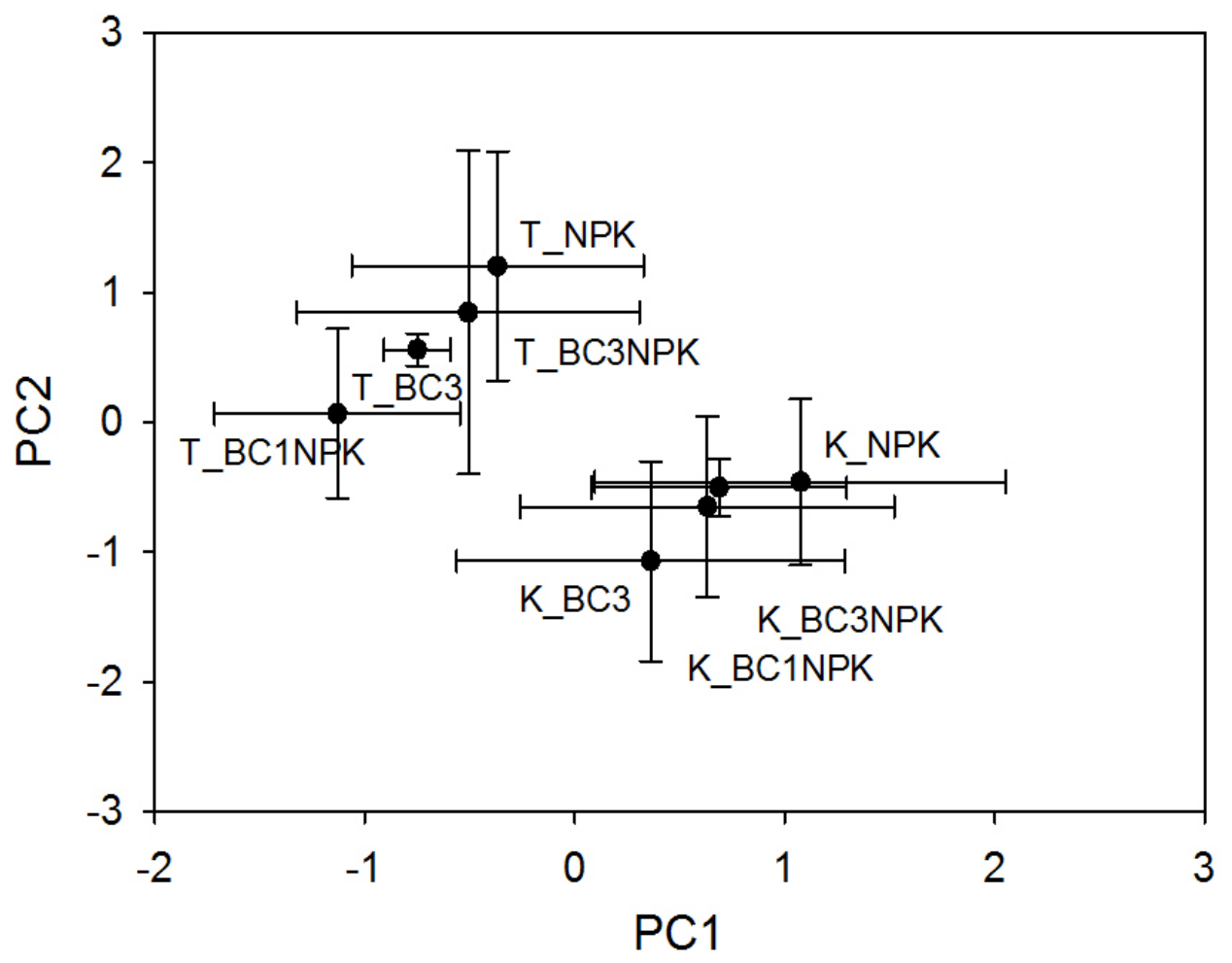

Fig. 7. Principal component analysis with grouping of various biochars and fertilization treatments from the field experiment. Error bars indicate standard deviation $\mathrm{T}=$ Traismauer; $\mathrm{K}=\mathrm{K}$ aindorf; $\mathrm{BC} 1 \mathrm{NPK}=1 \%$ biochar with nitrogen, $\mathrm{BC} 3 \mathrm{NPK}=3 \%$ biochar with nitrogen, $\mathrm{BC} 3=3 \%$ biochar without nitrogen, NPK= only fertilizer. For more data on the eigenvalue and variance see supplementary information. 


\section{Discussion}

This study investigated the effects of biochar on microbial communities under the greenhouse and field conditions. It was designed to identify (1) the influence of biochar on the soil microbial communities, (2) the reasons for these influence, and (3) the differences in the biochar effects caused by different application rates in soil, different pyrolysis temperature and the feedstock of biochar.

\section{Effects of biochar on the soil microbial biomass and community structure}

PLFA analysis of the greenhouse experiment showed little significant evidence for a positive effect of biochar on total microbial biomass. The absence of biochar effects on soil microorganisms has been documented by Castaldi et al. (2011) and Watzinger et al. (2013). At the same time however, no significant negative effect of biochar amendment on total microbial biomass was observed in the current study. Nevertheless, our principal component analysis of both experiments showed shifts in the microbial community. If microbially available carbon sources (e.g. plant residues or vegetable oil) are added to the soil, then soil microorganisms tend to react by increasing their biomass (Stemmer et al. 2007, Mellendorf et al. 2010). As we generally did not observe such an increase, we hypothesize that changes in microbial communities were largely caused by altered soil characteristics, as proposed by Watzinger et al. (2013), Mašek et al. (2011) and Lehmann et al. (2011). The behavior of the PLFA pattern also supports findings of O'Neil et al. (2009) and Anderson et al. (2011), that the biomass shifts apparently occurred at the level of single families, genera and species, and not in total microbial biomass. Additionally, we hypothesise that soil drying and pot preparation had strongly impacted soil microorganisms and caused major microbial mortality, followed by a large increase of microbial biomass.

\section{Linking soil microbial community changes to the soil properties in the greenhouse experiment}

Biochar-induced changes in the $\mathrm{C} / \mathrm{N}$ ratio, water holding capacity, $\mathrm{pH}$-value and nutrient availability affect soil fertility and microbial communities (Mao et al. 2012, Pietikäinen et al. 2000, Liang et al. 2010, Kolb et al. 2009). Soil samples from the greenhouse experiment were collected and analyzed at the start of the experiment and after seven month (Kloss et al. 2013). Adding biochar to the soil increased the $\mathrm{pH}$ value, EC, CEC, C/N ratio and $\mathrm{C}_{\text {org }}$ in the soil of this experiment. During the first seven months, the EC of the biochar-treated soil decreased, whereas CEC increased. The $\mathrm{C} / \mathrm{N}$ ratio increased after 51 and 170 days. We ascribed this increase to the absence of fertilization, which was omitted as a preparative management for the cultivation of clover. The reaction of PLFAs to the tested factors differed from soil to soil, and the correlations regarding the treatments with biochar differed from those without biochar. This supports a mainly indirect and complex effect of biochar on microbial communities, involving manifold effects of biochar on the soils' physical and chemical factors rather than a direct interaction such as biochar degradation by microorganisms as suggested by Mašek et al. (2011) and Lehmann et al. (2011).

One explanation for the observed strong correlation between the PLFAs and the C-and N-contents of soil is that they were the only parameters as determined in the same samples as the PLFA analysis. Beyond this, it is known that an increasing $\mathrm{C} / \mathrm{N}$ ratio changes the soil microbial community, e.g. favors fungal growth but limits bacterial abundance (Eiland et al. 2001). In contrast to this general model, we found not only negative correlations between PLFAs and $\mathrm{C} / \mathrm{N}$, but also strongly increasing microbial biomass with increasing $\mathrm{C} / \mathrm{N}$ ratio This mismatch is because $\mathrm{C} / \mathrm{N}$ ratios do not visualize the $\mathrm{C}$ - or $\mathrm{N}$-availability, and were probably caused by correlations from PLFAs with the $\mathrm{N}$-contents We found only little correlation between PLFAs and the C-content of soil. This leads to the conclusion that most of the $\mathrm{C}$ was not bio-available. Moreover, we found many correlations between PLFAs and N-contents of soil in Eschenau and Traismauer. Kaindorf showed correlations only with C-content and few correlations with nitrate. Nelissen et al. (2012) and Anderson et al. (2011) found that, depending on the soil and its nutrient status and dynamics, the processes of adsorption, immobilization, nitrification and mineralization will considerably affect nutrient availability and consequently soil microorganisms. Our interpretation is that the nutrient-rich soil (Kaindorf) showed no correlation with $\mathrm{N}$-contents and only few with nitrate because the microorganisms were already supplied with nutrients. The nutrient-poor soils with biochar from Traismauer and Eschenau showed many positive correlations with the N-content, nitrate and DOC; this could indicate that biochar enhanced the nutrient supply in these treatments. Kolb et al. (2009) and Steinbeiss et al. (2009) also reported that the increase in microbial biomass and respiration is higher with a low level of native SOM (soil organic matter) in the biocharamanded soils. They also determined that the increase in microbial habitat and available $\mathrm{C}$ in the SOM-poor soils was the main driver of this development. Note that, these soil bacteria are better adapted to nutrient-limited environments than those in soils with larger SOM. The absence of enhanced microbial biomass in the nutrient-rich soil of Kaindorf could also be reflecting to the high level of pre-existing microbial biomass (Ameloot et al. 2013). 
The correlations also showed that in the Planosol (Eschenau) many microorganisms benefited from the higher $\mathrm{pH}$ value. Like Watzinger et al. (2013), we found a strong increase of actinomycetes midway through of the experiment. This probably partly reflects their sensitivity to low pH values (Giri et al. 2013). The decrease in and low amount of fungal PLFAs could have also been a consequence of higher $\mathrm{pH}$, because fungi normally grow optimally in acidic soils (Aciego Pietri and Brookes 2009). The moderate $\mathrm{pH}$ value increase in the Cambisol (Kaindorf) and the Chernozem (Traismauer) showed no beneficial effects on microorganisms. In both soils, the pH value was close to neutral and its increase after biochar application was quite small which might explain the lack of response of the soil microorganisms.

A high pyrolysis temperature increases the micro-porosity in biochar and the fraction of finer biochar particles (Abit et al. 2012) and decreases the cation exchange capacity (CEC) of biochar (Lehmann et al. 2011). The process temperature also determines how much char, condensable liquid and gas will ultimately result from the pyrolysis. With increasing pyrolysis temperature the fractions of stable biochar compounds increase; this yields biochars with longer residence times in the soil, but with less labile compounds to promote microorganisms (Mašek et al. 2011, Lehmann et al. 2011). It is possible that the low pyrolysis temperature in treatment E_VN400 produced a larger labile C fraction; this, in turn, might have increased microbial PLFAs while the other investigated biochar treatments showed neutral or decreasing effects for microbial biomass. Nelissen et al. (2012) also reported increased activity of soil microorganisms in biochar pyrolysed at $350^{\circ} \mathrm{C}$ versus $550^{\circ} \mathrm{C}$. They attributed this to the larger labile carbon fraction in the lower temperature biochar. We observed increases of partly the same PLFAs already described by Watzinger et al. (2013) as taking part in biochar degradation. Our greenhouse experiment, however, provided no proof that they were involved in biochar degradation. One example of increased PLFA was 10Me18:0, actinomycetes. The reproduction of actinomycetes is slow and they prosper in nutrient limited soil. Actinomycetes can also degrade persistent and complex substrates and tend to build stable populations within the microbial community (Metting 1993). Additionally, Rhodococcus and Mycobacterium, members of the actinomycetes are known degraders of aromatic compounds (Johnsen et al. 2002, Ringelberg et al. 2001). Nonetheless, some of the volatile organic compounds can be toxic; moreover high salt levels from the labile biochar fraction could decrease microbial biomass (Lehmann et al. 2011, Spokas et al. 2011). Taghizadeh-Toosi et al. (2011) described VOCs from biochar as possible nitrification inhibitors. Kloss et al. (2013) and Deenik et al. (2011) found that the detrimental effects of VOCs in biochar-enriched soils were temporary. In our experiment, the stability of the total microbial biomass after biochar amendment confirmed that biochar toxicity played a minor role. Principal component analysis of the microorganism community, however, did show a separation of different treatments on day 0 and day 51 . On day 170 the biochar treatments showed no separation and the last sampling day showed a separation between treatments with biochar and without. This might be attributed to the loss / leaching of salts and the labile carbon fraction of the biochar.

\section{Comparison of soil microbial community growth and plant growth in the greenhouse experiment}

The first crop (mustard) of Eschenau showed clear differences between the biochar treatments and the control, but these differences were reduced and insignificant in the second (barley) and third crops (clover) (Kloss et al. 2013). This pattern was also partial reflected in the principal component analysis and the MANOVA of the microorganism community. The treatments with vineyard pruning showed, on days 10, 51 and 86 strong differences and on day 170 and 297 no difference, instead we found at day 170 and day 297 a difference between the treatments without biochar and the treatments with wood biochar. Generally, biochar application decreased the plant biomass of the first two crops (mustard and barley) in all soils. This might be related to shifts in micronutrient availability, or to the toxic effects of VOCs and/or polycyclic aromatic hydrocarbons (PAHs) (Kloss et al. 2013). We found no significant reduction of microbial biomass. Kloss et al. (2013) determined that the interaction of biochar application and $\mathrm{N}$ fertilization was only of minor importance for plant growth. Our analysis of PLFAs also showed no or little influence of biochar on the $\mathrm{N}$ related processes of microbial growth. In the Planosol (Eschenau) without biochar, PLFAs correlated with all three crops, whereas the treatment with biochar correlated only with the mustard crop. One interpretation is that, in the sandy Planosol without biochar, the interaction between plants and microorganisms is closed and has a stronger impact. This direct connection seemed to be decoupled through the biochar amendment. 


\section{Effects of biochar on soil microorganisms in the field}

In the field experiment, the $\mathrm{C} / \mathrm{N}$ ratio increased significantly after biochar addition, while the soil parameters $\mathrm{pH}$ value, EC and CEC were not influenced by this addition in the second vegetation period, when PLFA samples were collected. In Kaindorf, the yield of wheat (dry biomass) fell significantly under BC3 treatment compared to the other three treatments. The yield of sunflower in Traismauer showed a smaller difference between the BC3 and the NPK treatment (unpublished data). The reduced component factors of PCA from the microorganism PLFAs did not show the same distribution pattern as the crop yield of the corresponding treatments. There was no disadvantage of treatment BC3 found. The separation of treatments into two soil-groups was caused by principal component factor 2, which was largely defined through PLFAs from the microorganism group of fungi. This separation probably originated from the innately higher fungi content in the microorganism community of Traismauer soil. The trends and the separation of the treatments in the field experiment were comparable to those from the greenhouse experiment.

\section{Conclusion}

Biochar amendment to temperate agricultural soils did not increase or decrease total soil microbial biomass but caused minor shifts in the microbial communities using phospholipid fatty acid analyses. Only the biochar treatment Eschenau soil with vineyard pruning pyrolysed at $400^{\circ} \mathrm{C}$ showed a significant increase of microbial biomass in the greenhouse experiment possibly related to a larger labile fraction in biochar pyrolysed at lower temperature. The greenhouse pot experiment and the field experiments showed consistent results. Biochar application affected soil chemistry and physics and consequently microbial communities differently in the three different agricultural soils. In this context of complexity we could identify $\mathrm{pH}$ value being important, especially after biochar addition to the slightly acidic soil (Eschenau soil). Additionally, nutrient-status and -availability (N-content of the bulk soil; nitrate, ammonium and DOC of the soil solution) affected the microbial communities. We found that biochar enhanced the positive correlation between nutrients and microorganisms in the nutrient poor soils of Eschenau and Traismauer more than in the nutrient rich soil of Kaindorf. In our high quality agricultural soils the importance of biochar addition was rather carbon sequestration than soil amelioration.

\section{Acknowledgement}

This study was financed by the Austrian FFG, project nr. 825438, via the KLI.EN-funds programs “Neue Energien 2020".

\section{References}

Abit, S.M., Bolster, C.H., Cai, P. \& Walker, S.L. 2012. Influence of Feedstock and Pyrolysis Temperature of Biochar Amendments on Transport of Escherichia coli in Saturated and Unsaturated Soil. Environmental Science \& Technology 46: 8097-8105.

Aciego Pietri, J.C. \& Brookes, P.C. 2009. Substrate inputs and pH as factors controlling microbial biomass, activity and community structure in an arable soil. Soil Biology \& Biochemistry 41: 1396-1405.

Anderson, C.R., Condron, L.M., Clough, T.J., Fiers, M., Stewart, A., Hill, R.A. \& Sherlock, R.R. 2011. Biochar induced soil microbial community change: Implications for biogeochemical cycling of carbon, nitrogen and phosphorus. Pedobiologia - International Journal of Soil Biology, 54: 309-320.

Ameloot, N., Graber, E., Verheijen, F.\& De Neve, S. 2013. Interactions between biochar stability and soil organisms: review and research needs. European Journal of Soil Sience, 64: 379-390.

Bligh E. \& Dyer W. 1959. A rapid method of total lipid extraction and purification. Canadian Journal of Biochemistry and Physiology 37: 911-917.

Bücker, J. 2012. Effects of biochar on leachate characteristics and crop production of mustard (Sinapis alba) and barley (Hordeum vulgare) in a micro-lysimeter experiment on three agricultural soils in Austria. Diploma thesis, BTU Cottbus.

Brennan, P. J. 1988. Mycobacterium and other actinomycetes. In: Ratledge, C. and Wilkinson, S. G. (eds.). Microbial lipids. London: Academic Press. p. 204-298.

Brewer, C.E., Unger, R., Schmidt-Rohr, K. \& Brown, R.C. 2011. Criteria to Select Biochar for Field Studies based on Biochar Chemical Properties. Bioenergy Research 4: 312-323.

Castaldi, S., Riondino, M., Baronti, S., Esposito, F.R., Marzaioli, R., Rutigliano, F.A., Vaccari, F.P. \& Miglietta, F. 2011. Impact of biochar application to a Mediterranean wheat crop on soil microbial activity and greenhouse gas fluxes. Chemosphere 85: $1464-1471$.

Chan, K. Y. \& Xu, Z. 2009. Biochar: nutrient properties and their enhancement. In: Lehmann, J. and Joseph, S. (eds.). Biochar for Environmental Management. Earthscan, London: Science and Technology. p. 67-84. 
Cheng, C. H., Lehmann, J., Thies, J. E., Burton, S. D. \& Engelhard, M. H. 2006. Oxidation of black carbon by biotic and abiotic processes. Organic Geochemistry 37: 1477 - 1488.

Deenik, J.L., Diarra, A., Uehara, G., Campbell, S., Sumiyoshi, Y., \& Antal, M.J., 2011. Charcoal Ash and Volatile Matter Effects on Soil Properties and Plant Growth in an Acid Ultisol. Soil Science 176: 336-345.

Downie, A., Crosky, A. \& Munroe, P. 2009. Physical properities of biochar. In: Lehmann, J. \& Joseph, S. (eds.). Biochar for Environmental Management. Earthscan, London: Science and Technology. p. 13-29.

Downie, A.E., Van Zwieten, L., Smernik, R.J., Morris, S. \& Munroe, P.R. 2011. Terra Preta Australis: Reassessing the carbon storage capacity of temperate soils. Agriculture, Ecosystems \& Environment 140: 137-147.

Eiland, F., Klamer, M. Lind, A. M., Leth, M. \& Bååth, E. 2001. Influenc of initial C/N ratio on chemical and microbial composition during long term composting of straw. Microbial Ecology 41: 272-280.

Farrell, M., Kuhn,T.K., Macdonald, L.M., Maddern,T.M., Murphy, D.V., Hall, P.A., Pal Singh,B., Baumann, K., Krull, E.S. \& Baldock, J.A. 2013. Microbial utilisation of biochar-derived carbon. Science of the Total Environment, 465: 288-297.

Frostegård, Å. \& Bååth, E. 1996. The use of phospholipid fatty acid analysis to estimate bacterial and fungal biomass in soil. Biology and Fertility of Soils 22: 59-65.

Frostegård, Å., Tunlid, A. \& Bååth, E. 1991. Microbial biomass measured as total lipid phosphate in soils of different organic content. Journal of Microbiological Methods 14: 151-163.

Frostegård, Å., Tunlid, A. \& Bååth, E., 2011. Use and misuse of PLFA measurements in soils. Soil Biology and Biochemistry 43 : 1621-1625.

Giri, B., Giang, P.H., Kumari, R., Prasad, R. \& Varma, A. 2005. Microbial diversity in soils. In: Buscot, F. \& Varma, A. (eds.). Roles in Genesis and Functions. Berlin Heidelberg: Springer. Microorganisms in Soils. p.19-55.

Glaser, B., Lehmann, J. \& Zech, W. 2002. Ameliorating physical and chemical properties of highly weathered soils in tropics with charcoal - a review. Biology and Fertility of Soils 35: 219-230.

Glaser, B. \& Birk, J.J. 2012. State of the scientific knowledge on properties and genesis of Anthropogenic Dark Earths in Central Amazonia (terra preta de Índio). Geochimica et Cosmochimica Acta 82: 39-51.

Grossman, J.M., O’Neill, B.E., Tsai, S.M., Liang, B., Neves, E., Lehmann, J. \& Thies, J.E. 2010. Amazonian Anthrosols Support Similar Microbial Communities that Differ Distinctly from Those Extant in Adjacent, Unmodified Soils of the Same Mineralogy. Microbial Ecology 60: 192-205.

Johnsen, A.R., Winding, A., Karlson, U. \& Roselev, P. 2002. Linking of microorganisms to phenanthrene metabolism in soil by analysis of (13)C-labelled cell lipids. Applied Environmental Microbiology 68: 6106-6113.

Kloss, S., Zehetner, F., Wimmer, B., Bücker, J. \& Soja, G. 2013. Biochar application to temperate soils: Effects on soil fertility and crop growth under greenhouse conditions. Plant Nutrition and Soil Science 000:1-13.

Kolb, S.E., Fermanich, K.J. \& Dornbush, M.E. 2009. Effect of Charcoal Quantity on Microbial Biomass and Activity in Temperate Soils. Soil Science Society of America Journal 73:1173.

Kolton, M., Meller Harel, Y., Pasternak, Z., Graber, E.R., Elad, Y. \& Cytryn, E. 2011. Impact of Biochar Application to Soil on the Root-Associated Bacterial Community Structure of Fully Developed Greenhouse Pepper Plants. Applied and Environmental Microbiology 77: 4924-4930.

Lehmann, J., Gaunt, J. \& Rondon, M. 2006. Bio-char Sequestration in Terrestrial Ecosystems - A Review. Mitigation and Adaptation Strategies for Global Change 11: 395-419.

Lehmann, J., Rillig, M.C., Thies, J., Masiello, C.A., Hockaday, W.C. \& Crowley, D. 2011. Biochar effects on soil biota - A review. Soil Biology and Biochemistry 43: 1812-1836.

Liang, B., Lehmann, J., Sohi, S. P., Thies, J., O’Neill, B., Trujillo, L., Gaunt, J., Solomon, D., Grossman, J., Neves, E. G \& Luizão, F. J. 2010. Black carbon affects the cycling of non-black carbon in soil. Organic Geochemistry 41: $206-213$.

Mao, J.-D., Johnson, R.L., Lehmann, J., Olk, D.C., Neves, E.G., Thompson, M.L. \& Schmidt-Rohr, K. 2012. Abundant and Stable Char Residues in Soils: Implications for Soil Fertility and Carbon Sequestration. Environmental Science \& Technology 46: 9571-9576.

Mašek, O., Brownsort, P., Cross, A. \& Sohi, S. 2011. Influence of production conditions on the yield and environmental stability of biochar. Fuel 103: 151-155.

Mellendorf, M., Soja, G., Gerzabek, M.H. \& Watzinger, A. 2010. Soil microbial community dynamics and phenanthrene degradation as affected by rape oil application. Applied Soil Ecology 46: 329-334.

Metting, F.B. 1993. Structure and physiological ecology of soil microbial communities. In: Metting, F.B. (ed.). Soil microbial ecology - applications in agricultural and environmental management. New York: Library of Congress. p. 3-26.

Moss, C. W. \& Daneshvar, M. I. 1992. Identification of some uncommon monounsaturated fatty acids of bacteria. Journal of Clinical Microbiology 30: 2511-2512.

Nelissen, V., Rütting, T., Huygens, D., Staelens, J., Ruysschaert, G.\& Boeckx, P. 2012. Maize biochars accelerate short-term soil nitrogen dynamics in a loamy sand soil. Soil Biology and Biochemistry 55: 20-27.

Olsson, P. A., BÅÅth, E., Jakobsen, I. \&Söderström, B. 1995. The use of phospholipid and neutral lipid fatty acids to estimate biomass of arbuscular mycorrhizal fungi in soil. Mycological Research 99: 623-629.

O’Neill, B., Grossman, J., Tsai, M.T., Gomes, J.E., Lehmann, J., Peterson, J., Neves, E.\& Thies, J.E. 2009. Bacterial Community Composition in Brazilian Anthrosols and Adjacent Soils Characterized Using Culturing and Molecular Identification. Microbial Ecology 58: 23-35.

Paul, E.A. \& Clark, F.E. 1996. Soil microbiology and biochemistry. $2^{\text {nd }}$ ed. San Diego, New York: Academic Press. 340 p. 
Pietikäinen, J., Kiikkilä, O. \& Fritze, H. (2000): Charcoal as a habitat for microbes and its effect on the microbial community of the underlying humus. Oikus 89: 231-242.

Quilliam, R.S., Marsden, K.A., Gertler, C., Rousk, J., DeLuca, T.H. \& Jones, D.L., 2012. Nutrient dynamics, microbial growth and weed emergence in biochar amended soil are influenced by time since application and reapplication rate. Agriculture, Ecosystems \& Environment 158: 192-199.

Ringelberg, D.B., Tally J.W., Perkins E.J., Tucker, S.G., Luthy, R.G., Bouwer, E.J. \& Fredrickson, H.L. 2001. Succession of Phenotypic, Genotypic, and Metabolic Community Characteristics during In Vitro Bioslurry Treatment of Polycyclic Aromatic Hydrocarbon-Contaminated Sediments. Applied and Environmental Microbiology 67: 1542-1550.

Schimel, J., Balser, T.C. \& Wallenstein, M. 2007. Microbial stress - response physiology and its implications for ecosystem function. Ecology 88: 1386-1394.

Spokas, K.A., Cantrell, K.B., Novak, J.M., Archer, D.W., Ippolito, J.A., Collins, H.P., Boateng, A.A., Lima, I.M., Lamb, M.C., McAloon, A.J., Lentz, R.D.\& Nichols, K.A., 2012. Biochar: A Synthesis of Its Agronomic Impact beyond Carbon Sequestration. Journal of Environment Quality 41: 973.

Spokas, K.A., Novak, J.M., Stewart, C.E., Cantrell, K.B., Uchimiya, M., DuSaire, M.G. \& Ro, K.S. 2011. Qualitative analysis of volatile organic compounds on biochar. Chemosphere 85: 869-882.

Steinbeiss, S., Gleixner, G. \& Antonietti, M. 2009. Effect of biochar amendment on soil carbon balance and microbial activity. Soil Biology \& Biochemistry 41: 1301-1310.

Stemmer, M., Watzinger, A., Blochberger, K., Haberauer, G. \& Gerzabek, M. 2007. Linking dynamics of soil microbial phospholipid fatty acids to carbon mineralization in ${ }^{13} \mathrm{C}$ natural abundance experiment: Impact of heavy metals and acid rain. Soil Biology \& Biochemistry 39: 3177-3186.

Taghizadeh-Toosi, A., Clough, T.J., Condron, L.M., Sherlock, R.R., Anderson, C.R. \& Craigie, R.A. 2011. Biochar Incorporation into Pasture Soil Suppresses in situ Nitrous Oxide Emissions from Ruminant Urine Patches. Journal of Environment Quality 40: 468.

Waldrop, M.P., Balser, T.C. \& Firestone, M.K. 2000. Linking microbial community composition to function in a tropical soil. Soil Biology \& Biochemistry 32: 1837-1846.

Watzinger, A., Feichtmair, S., Kitzler, B., Zehetner, F., Kloss, S., Wimmer, B., Zechmeister-Boltenstern, S. \& Soja, G. 2013. Soil microbial communities responded to biochar application in temperate soils and slowly metabolized ${ }^{13} \mathrm{C}$ labelled biochar as revealed by ${ }^{13} \mathrm{C}$ PLFA analyses - results from a short term incubation and pot experiment. European Journal of Soil Science: online Doi: 10.1111/ejss.12100.

White, D. C. \& MacNaughton, S. J. 1997. Chemical and molecular approaches for rapid assessment of the biological status of soils. In: Pankhurst, C.E, Doube, B. M. \& Gupta, V. V. S. R. (eds.). Biological Indicators of Soil Health. Wallingford, UK: CAB International. p. 371-396.

Wilkinson, S.G. 1988. Gram-negative bacteria. In: Ratledge, C. \& Wilkinson, S.G. (eds.). Microbial Lipids. London: Academic Press. p. 299-489.

Zak, J. C., Willig, M. R., Moorhead, D. L. \& Wildman, H. G. 1994. Functional diversity of microbial communities: A quantitative approach. Soil Biology \& Biochemistry 26: 1101-1108.

Zimmerman, A.R. 2010. Abiotic and microbial oxidation of laboratoryproduced black carbon (biochar). Environmental Science \& Technology 44: 1295-1301. 


\section{Appendix:}

\section{Material and methods}

For all soils, the $\mathrm{pH}$-value, electric conductivity $(\mathrm{EC})$ was measured through saturation water extract method according to standard method ÖNORM L 1092 and the cation exchange capacity (CEC) was measured according to ÖNORML 1086 (2001). $5 \mathrm{~g}$ of soil were mixed with $100 \mathrm{~mL} 0.1 \mathrm{M} \mathrm{BaCl}_{2}$ solution and settled overnight. Carbonate carbon content (Cinorg), soil organic carbon content (Corg) and nitrogen ( $\mathrm{N}$ ) were determined with dry burning according to standard methods (ÖNORM L 1080, ÖNORM L 1095). Particle size was determined with a sedigraph (modified method based on ÖNORM 1061-1 for coarse soil and ÖNORM L 1061-2 for fine soil, respectively).

ÖNORM L 1061-1. 2002. Physikalische Bodenuntersuchungen - Bestimmung der Korngrößenverteilung des Mineralbodens -Teil 1: Grobboden.

ÖNORM L 1061-2. 2002. Physikalische Bodenuntersuchungen - Bestimmung der Korngrößenverteilung des Mineralbodens - Teil 2: Feinboden.

ÖNORM L 1080-1. 2001. Chemische Bodenuntersuchungen - Bestimmung des organischen Kohlenstoffes durch trockene Verbrennung mit und ohne Berücksichtigung von Carbonaten.

ÖNORM L 1086-1. 2001. Chemische Bodenuntersuchungen - Bestimmung der austauschbaren Kationen und der effektiven Kationen-Austauschkapazität (KAKeff) durch Extraktion mit Bariumchlorid-Lösung.

ÖNORM L 1092. 2005. Chemische Bodenuntersuchungen - Extraktion wasserlöslicher Elemente und Verbindungen.

ÖNORM L 1095 (2002): Chemische Bodenuntersuchungen - Bestimmung des Gesamtstickstoffgehaltes durch trockene Verbrennung.

Supplementary information to figures 4,5 and 7.

\begin{tabular}{|c|c|c|c|c|c|c|c|}
\hline $\begin{array}{l}\text { greenhouse } \\
\text { figure } 4\end{array}$ & & $x$ axis & eigenvalue & variance (\%) & y axis & eigenvalue & $\begin{array}{c}\text { variance } \\
(\%)\end{array}$ \\
\hline day 10 & pc 2 & 2.36 & 9.44 & pc 4 & 1.55 & 6.20 & \\
\hline day 51 & pc 2 & 2.31 & 9.23 & pc5 & 1.23 & 4.94 & \\
\hline day 170 & pc 1 & 18.83 & 75.32 & pc 3 & 1.15 & 4.60 & \\
\hline day 297 & pc 1 & 17.28 & 69.11 & pc 3 & 2.02 & 8.09 & \\
\hline $\begin{array}{l}\text { greenhouse } \\
\text { figure } 5\end{array}$ & & $x$ axis & eigenvalue & variance (\%) & $y$ axis & eigenvalue & $\begin{array}{c}\text { variance } \\
(\%)\end{array}$ \\
\hline day 10 & pc 1 & 19.52 & 78.09 & pc 2 & 1.48 & 5.93 & \\
\hline day 51 & pc 1 & 18.62 & 74.48 & pc 3 & 1.22 & 4.86 & \\
\hline day 170 & pc 2 & 1.81 & 7.25 & pc 3 & 1.02 & 4.07 & \\
\hline day 297 & pc 1 & 21.3 & 85.20 & pc 2 & 1.38 & 5.51 & \\
\hline $\begin{array}{l}\text { field } \\
\text { figure } 7\end{array}$ & & $x$ axis & eigenvalue & variance (\%) & $y$ axis & eigenvalue & $\begin{array}{c}\text { variance } \\
(\%)\end{array}$ \\
\hline & pc 1 & 16.87 & 64.90 & pc 2 & 5.61 & 21.59 & \\
\hline
\end{tabular}

$\mathrm{pc}=$ principal component factor. 


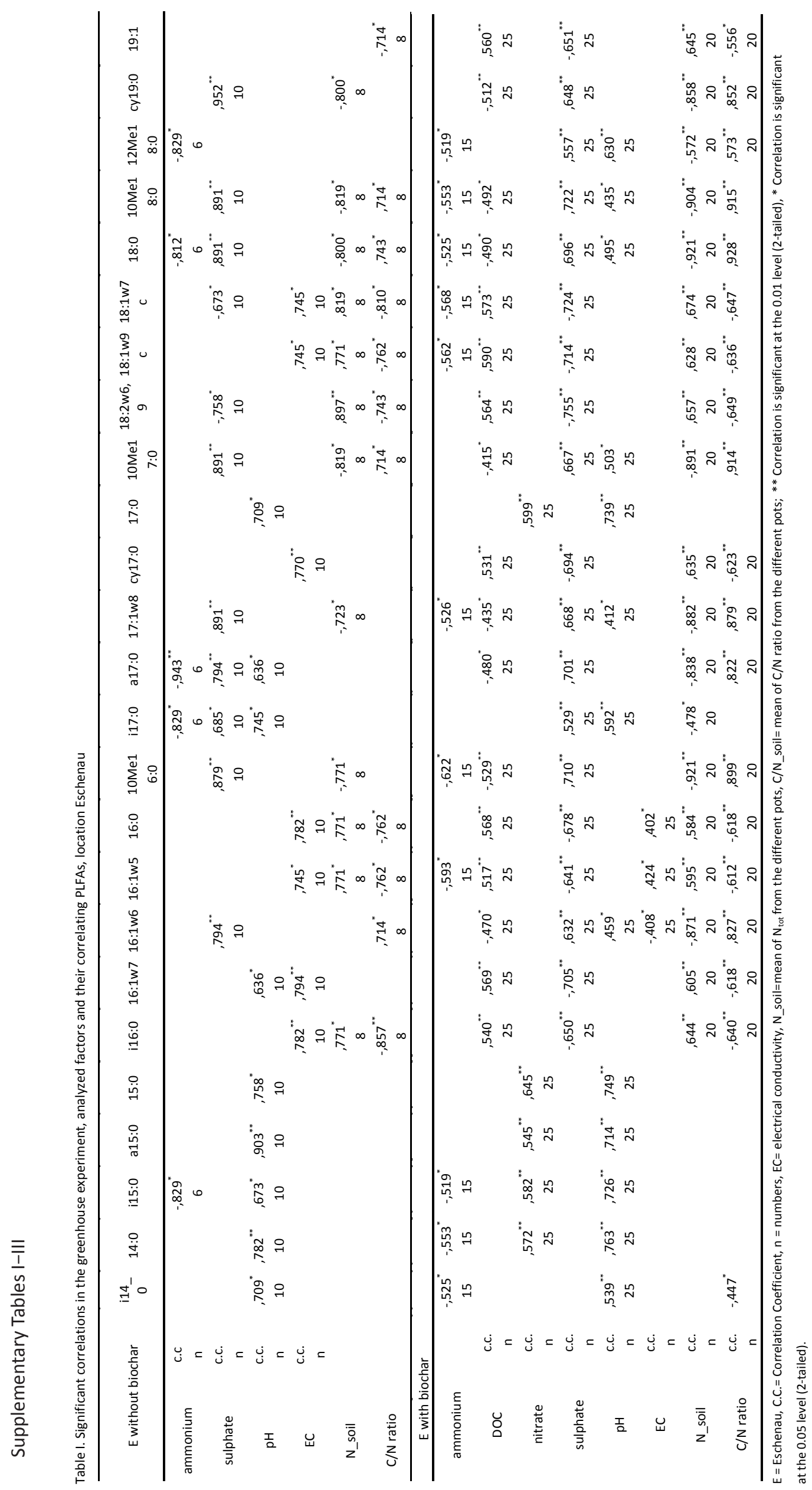




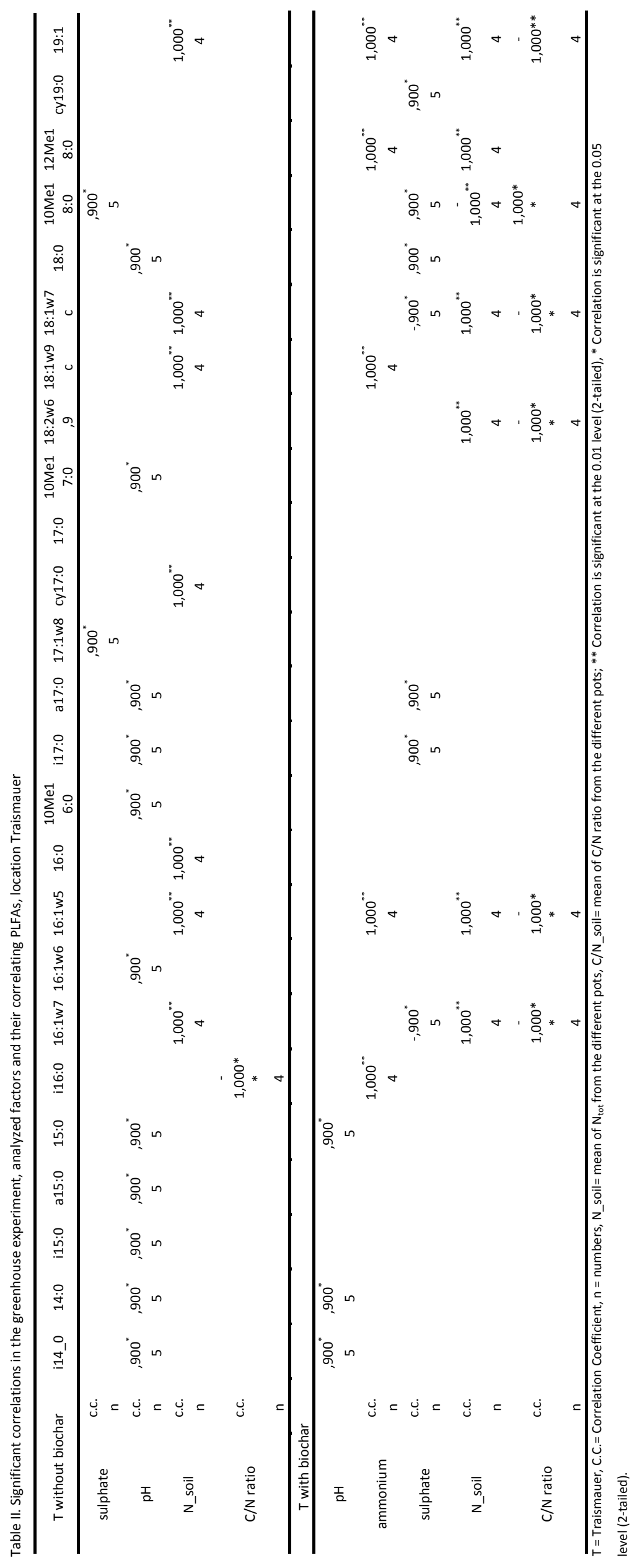




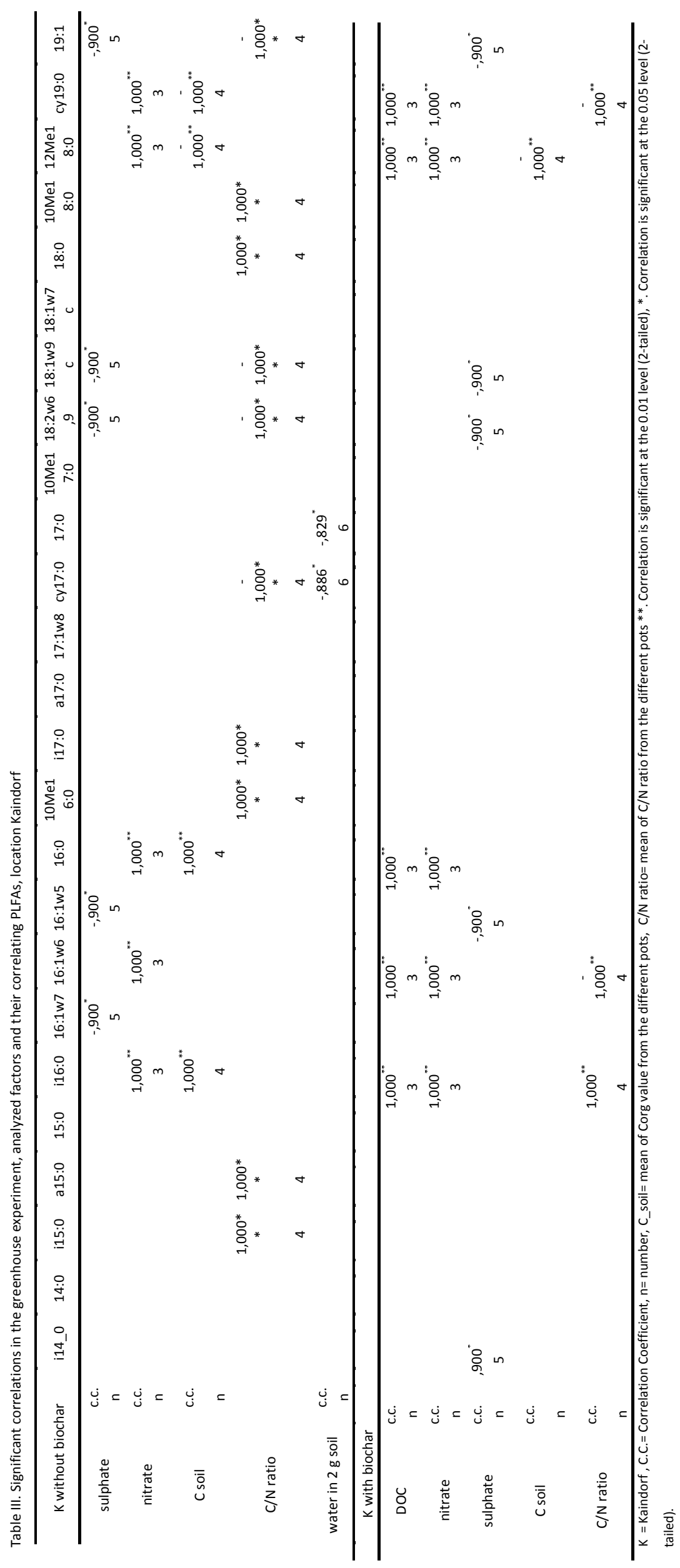

